\title{
Simone Martini's Guidoriccio Fresco: The Polemic Concerning its Origin Reviewed, and the Fresco Considered as Serving the Military Triumph of a Tuscan Commune
}

\author{
Joseph Polzer
}

Volume 14, numéro 1-2, 1987

URI : https://id.erudit.org/iderudit/1073451ar

DOI : https://doi.org/10.7202/1073451ar

\section{Aller au sommaire du numéro}

\section{Éditeur(s)}

UAAC-AAUC (University Art Association of Canada | Association d'art des universités du Canada)

\section{ISSN}

0315-9906 (imprimé)

1918-4778 (numérique)

Découvrir la revue

Citer cet article

Polzer, J. (1987). Simone Martini's Guidoriccio Fresco: The Polemic Concerning its Origin Reviewed, and the Fresco Considered as Serving the Military

Triumph of a Tuscan Commune. RACAR : Revue d'art canadienne / Canadian Art Review, 14(1-2), 16-69. https://doi.org/10.7202/1073451ar

\section{Résumé de l'article}

Cet article présente un compte rendu de la documentation parue sur la controverse qui entoure l'auteur et la date de la fresque de Guidoriccio da Fogliano, au Palazzo Pubblico de Sienne; il examine aussi les problèmes qu'a soulevés la découverte d'une nouvelle fresque sur le même mur. Nous confirmons l'exactitude de l'attribution conventionnelle de l'éphigie équestre à Simone Martini, de même que la légitimité de l'identité pour des raisons documentaires et iconographiques. Pour ce qui est de la fresque découverte récemment (dont la date se situe entre 1310 et 1315), nous réfutons

l'assimilation de la " ville " à Giuncario ou Arcidosso. Au cours de l'examen de la fresque de Guidoriccio, nous prêtons attention aux marques techniques, aux comptes rendus du restaurateur, à la relation entre la fresque et Simone Martini et à son style de décoration à l'étampe, ainsi qu'à la présence de rainures sur la " mappamondo ", sur la bordure du bas, et finalement au sens de la bordure de la fresque dans le contexte des oeuvres ultérieures de Sodoma. En dernier lieu, nous nous concentrons sur la représentation du siège de Montemassi, les témoignages que fournissent les chroniques du temps et leur lien avec ce que l'on voit sur la fresque, en particulier la manière dont sont représentés les « battifoli », et la précision topologique de la peinture des objets dans le panorama.
Tous droits réservés ( $)$ UAAC-AAUC (University Art Association of Canada | Association d'art des universités du Canada), 1987
Ce document est protégé par la loi sur le droit d'auteur. L’utilisation des services d'Érudit (y compris la reproduction) est assujettie à sa politique d'utilisation que vous pouvez consulter en ligne.

https://apropos.erudit.org/fr/usagers/politique-dutilisation/ 


\section{Simone Martini's Guidoriccio Fresco: The Polemic Concerning its Origin Reviewed, and the Fresco Considered as Serving the Military Triumph of a Tuscan Commune}

JOSEPH POLZER

University of Calgary

\section{RÉSLMÉ}

Cet article présente un compte rendu de la documentation parue sur la controverse qui cntoure l'autcur ct la date de la fresque de Guidoriccio da Fogliano, au Palazzo Pubblico de Sienne; il examine aussi les problèmes qu'a soulcvés la découverte d'unc nouvelle fresque sur le même mur. Nous confirmons l'exactitude de l'attribution conventionnelle de l'éphigie équestre à Simone Martini, de même que la légitimité de l'identité pour des raisons documentaires et iconographiques. Pour ce qui est de la fresque découverte récemment (dont la date sc situe cntre 1310 et 1315), nous réfutons l'assimilation de la "ville "à Giuncario ou Arcidosso. Au cours de l'examen de la fresque de (juidoriccio, nous prêtons attention aux marques techniques, aux comptes rendus du restaurateur, à la relation entre la fresque et Simone Martini et à son style de décoration à l'étampe, ainsi qu'à la préscnce de rainures sur la "mappamondo", sur la bordure du bas, ct finalement au sens de la bordure de la fresque dans le contexte des ocuvres ultéricures de Sodoma. En dernier licu, nous nous concentrons sur la représcntation du siège do Montemassi, les témoignages que fournissent les chroniques du temps et leur lien avec ce que l'on voit sur la fresque, cn particulicr la manière dont sont représcntés les "battifoli ". ct la précision topologique de la peinture des objets dans le panorama.
One of the most celebrated frescoes of the Sienese proto-Renaissance - the equestrian portrait of Guidoriccio da Fogliano, general of the Sienese forces, represented at the siege of Montemassi, located in the Palazzo Pubblico in Siena-has in recent years become the subject of heated debate (Fig. 4). The art historians Michael Mallory and Gordon Moran affirmed in print in 1977 that this fresco is not by the hand of Simone Martini, to whom it has been traditionally attributed.' They also insisted that the fresco postdates the trecento by centuries and maintain these views to the present. ${ }^{2}$ Needless to say, their assertions provoked a great deal of consternation, considering that the

1 Their views werc first published in Paragone, xxvin, 333 (November 1977), 81f1.

2 See, most recently, their article in Burlington Magazine (April 1986), 250rf., where additional bibliography can be found. fresco in question, gracing the Sala del Consiglio (later assuming the name of the Sala del Mappamondo) where the city's legislative body deliberated, is a living symbol of Sicna's pride in its past.

Their challenge brought to light many lacunac in our knowledge of Siena's history during the proto-Renaissance and triggered a great deal of study focusing on the early decoration of the Palazzo Pubblico and the events surrounding Guidoriccio's presence in Siena. In the wake of their challenge it was decided that the fresco be subjected to a technical examination, carried out in 1979 by Leonetto Tintori. ${ }^{3}$ Significantly, Tintori's examination led $t o$ the discovery of Iraces of another fresco situated directly below it. It was uncovered, and restored along with the Guidoriccio

3 This technical cxamination was funded at my request by the MacDonald Stewart Foundation of Montreal. 
fresco, by Giuseppe Gavazzi, who completed this project in 1981. The new fresco represents two men standing in front of a modest hill town. It constitutes without question the most significant contribution of recent years to the known artistic production of the Sienese proto-Renaissance. Given its proximity to the Guidoriccio, the new fresco has itself become a factor in the discussion. Concurrent with this restoration project, Sienese authorities appointed a number of specialists to an official commission charged with the examination of the Guidoriccio problem. Their examination reaffirmed the traditional view that Simone Martini was the painter and resulted in two complementary articles which appeared early in 1982 . For his part Luciano Bellosi referred to a number of close stylistic comparisons linking the Guidoriccio fresco to Simone's certain works. ${ }^{4}$ The second article, by Max Seidel, replete with useful archival source material, focused on the early pictorial representation in Siena's Palazzo Pubblico of a number of towns acquired by Siena during the early trecento. He identified the mountain hamlet depicted on the newly discovered fresco as Giuncarico, obtained by the Sienese in $1314 .^{5}$ This identification has been questioned by Mallory and Moran who consider it to be the town of Arcidosso, painted by Simone Martini in the Palazzo Pubblico in $1331 .^{6}$

Unaware of the existence of this official commission and of the preparation of these studies, I published my views on the Guidoriccio fresco in the Jahrbuch der Berliner Museen of $1983 .^{7}$ I sought to approach the problem of the fresco's origin and meaning from a number of diverse vantage points; these sustained Simone's parentage. My

4 L. Bellosi, “'Castrum pingatur in palatio.' 2. Duccio e Simone Martini pittori di castelli senesi a l'esemplo come erano," Prospettiva, xxvin (January 1982), 5lff. The main thrust of Bellosi's article (4lff.) concerned, however, his attribution of the new fresco to Duccio, which has not been universally accepted. Enzo Carli attributes it to Memmo di Filippuccio, in La pittura senese del trecento (Milan, 1981), 106ff., and so does Christina de Benedictis (La pittura in Italia, il duecento e il trecento [Venice, 1966], I, 334). James Stubblebine (in a paper presented at the College Art Association meeting in Philadelphia in February 1983) and Cesare Brandi (in the Corriere della Sera, 28 March 1981) attribute the new fresco to the young Pietro Lorenzetti. Sce also the fresco's consideration by Gabriele Borghini, in many authors, Palazzo Pubblico di Siena. Vicende costruttive de decorazione (Siena, 1983), 21f., with reference to its various attributions.

5 M. Seidel, "'Castrum pingatur in palatio.' 1 . Ricerche storiche e iconografiche sui castelli dipinti nel Palazzo Pubblico di Siena," Prospettiva, xxvirI (January 1982), 17-41.

6 Sce most recently their article in Burlington Magazine (April 1986), 25Iff.

7 J. Polzer. "Simone Martini's (;uidoriccio da Fogliano: A New Appraisal in the Light of a Recent Technical Examination," Jahrbuch der Berliner Museen (1983), 103-41. stylistic comparisons corresponded substantially to those offered by Bellosi. I underscored the close connection in ornamental technique with Simone Martini's "certain" frescoes, and I confirmed the obvious identity of the rider as Guidoriccio da Fogliano-which Mallory and Moran had doubted ${ }^{8}$ - by documenting that the decoration on his cloak and the horse's gualdrappa represents the Da Fogliano family coat-of-arms. Since these articles were written there has been considerable further speculation. For what this may be worth, one obvious step that might contribute to the resolution of this dispute still remains to be taken: the examination of the connection of the Guidoriccio fresco with Lippo Vanni's Battle of the Val di Chiana where their respective walls meet in a corner of the Sala del Mappamondo (more about this later). I signalled the need for doing so in a paper presented in Rome in June 1984 which dealt exclusively with the technical data concerning the two frescoes in question. ${ }^{9} \mathrm{I}$ was pointing ahead towards the Simone Martini congress held in Siena in March 1985, hoping that by then this examination might have been realized. It has not yet taken place. Mallory and Moran's latest contribution in the Burlington Magazine of 1986 was accompanied by Andrew Martindale's article representing a pro-Simone position which, however, requires careful scrutiny (see Appendix). ${ }^{10}$

How precisely ought one to deal with the Guidoriccio fresco in the light of the ongoing polemic? One must strive to present one's case considered from multiple vantage points as coherently as possible. Extraneous issues must be excluded. Neither the veracity of Seidel's arguments for identifying the hill town on the new fresco as Giuncarico ${ }^{11}$ nor Bellosi's thesis that Duccio was its painter is of primary concern here-apart from the general theme of their connecting the new fresco to the early second decade of the century when the new Palazzo Pubblico had just been recently completed and its walls were substantially still barren of images. Without detracting from the positive aspects of Mallory and Moran's challenge, one should take cognizance of certain limitations in their arguments. Essentially, they have "taken away" the au-

8 See note 1. Mallory and Moran do not comment on the rider's identity in their recent article in the Burlington Magazine (April 1986)

$9 \mathrm{~J}$. Polzer. "The Technical Evidence and the (Origin and Meaning of Simone Martini's Guidoriccio Fresco in Siena," RACAR, XII, 2 (1985), 143-48.

10 A. Martindale, "The Problem of 'Guidoriccio,"' Burlington Magazine (April 1987), 259-72.

11 Mallory and Moran, who disagree with Scidcl, have uncovered new and interesting information concerning Siena's conflict during the years 1311-14 with the counts of Elci, the rulers of Giuncarico (Burlington Magazine [April 1986], 252f.). 
thorship of the fresco without supplying an acceptable positive alternative: a persuasive explanation of circumstances accounting for the fresco's creation at an as yet unspecified later historic moment. In all their publications, they avoid stylistic scrutiny of their own. They have preferred to defer to the opinions of certain respected authorities conforming to their views - to Federico Zeri and Giuliano Briganti. ${ }^{22}$ In key instances requisite historical information is lacking. For example, when introducing seals of Arcidosso that they consider to have a direct iconographic connection to the new fresco, they omit considering the seals' date of origin. ${ }^{13}$ Neither did they consider the date (actually nincteenth century) of a Paduan manuscript which gives Guidoriccio a different coat-of-arms from the one appearing on the Sienese equestrian figure. ${ }^{14}$ In the light of the developing discussion it is difficult to keep track of what Mallory and Moran really affirm. In their most recent article in the Burlington Magazine they make no reference to whether they still insist, as they once did, that the rider cannot be Guidoriccio, or how, if it is Guidoriccio, they would explain the creation of so prominent a retrospective portrait of this general at a much later time. Obvious sources representing an opposing viewpoint are excluded from their discussion. Witness, for example, the absence of Pompeo Litta's account of the Guidoriccio fresco in his well-known Celebri famiglie italiane as the principal historical record of the coat-of-arms of the Da Fogliano family. ${ }^{15} \mathrm{Mal}-$ lory and Moran have also indicated that they were not allowed close access to these frescoes for the purpose of examining certain technical details. This does not mesh with the facts. I myself invited Gordon Moran to climb on the scaffold at the time of Leonetto 'Tintori's initial examination of the Guidoriccio fresco. As recently as in the Burlington Magazine article of 1986 Mallory and Moran still maintain, contrary to the findings of both restorers and other observers who controlled the respective superposition of the plaster layers, ${ }^{16}$ that the

12 F. \%eri, "Guidoriccio due volte sfregiato," La Stampa (Turin), 4 July 1981; G. Briganti, "I a disfida di Guidoriccio," La Repubblica (Rome), 25 January 198.5.

13 These seals of Arcidosso are reproduced in Mallory and Moran, Notizze d'Arte, Siena (May-June 1983), 53 figs. 3 and 4; also in News from RILA, "(February 1984), ligure on page 11.

14 The ninetcenth-century manuscript in question is the limporio universale delle famiglie in the Museo Civico of Padua. The coat-of-arms is reproduced in Mallory and Moran, Notizie d'Arte, Siena (May-June 1983), 52 fig. 2. I am grateful for this information to Dottoressa M. Blason and Dottor G. Zampieri.

15 P. Litta, Famighe celebri italiane, Ser. I C-C; "Fogliani di Reggio," pls. Iff.; pl. 1 is dated 1834.

16 See the technical reports of both Giuseppe Gavazit and
Guidoriccio fresco might well postdate the Sodoma frescoes situated below on the same wall. ${ }^{17}$ Conversely, Mallory and Moran have felt free to adopt Gavazzi's assumption that the intonaco of the Guidoriccio fresco leans against - that is, follows after - the adjacent Battle of the Val di Chiana by Lippo Vanni which dates to 1363 with a certainty hardly reflected in Gavazzi's own account (see below). For what this may be worth, as Luciano Cateni has indicated, ${ }^{18}$ Tizio $^{19}$ and Tommasi, ${ }^{20}$ two sixteenth-century Sienese historians, already referred to Guidoriccio's presence in the Sala del Mappamondo. All this notwithstanding, the objective queries made by Mallory and Moran are welcome and must be considered dispassionately.

\section{THF, NEW FRISCO}

We shall consider in chronological order the early decoration of the wall in question. The earliest extant element is the new fresco (Fig. 5). Of the figural composition to the left of the mountain hamlet only half remains. ${ }^{21}$ The right border of Sodoma's later fresco laps over the man holding the gloves. These figures were obliterated and

Lconetto 'I"intori which are available at the library' of the Kunsthistorisches Institut in Florence. Gavazzi writes and Tintori concurs that "Questo rifacimento linitial restoration of the Guidoriccio fresco comprising the fort of Montemassi depicted at the left side] e da attribuirsi ad un periodo precedente all'intervento del Sodoma che nella stessa parctc dipinge due santi, uno dei quali con la parte superiore sormonta leggermente gli intonaci sopra descritti."

17 Burlington Magazine (April 1986), 256 п. 37

18 In a paper presented at the Simone Martini congress held in Siena in March 1985, which will appear in the acts of the congress.

19 "Guido Riccius pictus in aula... Hic ille est qui in aula dominorum senensium pictus est in capite mappemundi rotunde ubi Montis Massici picta est obsidio" (Siena, Biblioteca Comunale, Ms. B. A. V. Chigi, G.I. 33, x, 40).

20 G. Tommasi, Dell'Historie di Siena (Venice, 1625-26), 11, 319: "gli [(;uidoriccio] fù fatto honorata sepultura a San Domenico, essendo per prima stato honorato della Republica d'una Statua a cavallo dipenta nella Sala delle Balestre hora del Consiglio di mano di Simone Martini sommo pittore de suoi tempi... che si vede fin'hoggi sopra il Mappamondo con l'impresa di Montemassi." The quotations in this and the previous note, and also the reference to Cateni, are taken from Martindale, "The Problem of "Guidoriccio," "260f. See also a sixteenth. contury marginal gloss in a Biccherna volume which, according to Stefano Moscadelli, is by the hand of the historian Celso Cittadini (1553-1627), stating that Guidoriccio "lć] dipinto a cavallo nella sala del Consiglio di mano di Simone Martini da Siena," referred to by Seidel, "'CasIrum pingatur in palatio," "20. As this article goes to press, I have just been informed that Luciano Cateni's article "'Testimonianza sul 'Guidoriccio' anteriori al Della Valle," has appeared in Prospettiva, xi.1 (April 1985), 46-51.

$21 \mathrm{From}$ the composition of the two remaining figures it can be proposed that a third figure stood at the left of them, in which case figures and landscape would be in balance. 
covered with azurite blue prior to the superposition over the fresco of Ambrogio Lorenzetti's Mappamondo in 1345: a circular map of the world with Siena at the centre, which was mounted on wood and could be rotated.

The style of the new fresco has been considered at length by Luciano Bellosi. ${ }^{22}$ As already noted, he considers its painter to be Duccio, and draws on many comparisons with the narrative scenes from Duccio's Cathedral Maestà. As regards the question of the new fresco's chronology, these cornparisons are convincing, especially those regarding the vertically rippling jagged rocks and aspects of the quite realistic and detailed architecture. Witness, for example, the tiny walled fort set on top of the mountain right beside Christ tempted by the devil on the Frick Collection panel (Fig. 6): it is surely based on actual example rather than pictorial stereotype. However, as is apparent from the documents, Duccio was widely assisted in the production of the Maesta. I find it impossible to separate clearly Duccio's contributions from those of his assistants or collaborators. ${ }^{23}$ Bcllosi's discussion rivets the new fresco close to Duccio's Maestà. Its figural style, however, points away from Duccio, as is seen in the general stiffness of the figures' poses and the repeated verticality of their dresses' folds. Duccio's dynamic and highly diversified garment fold arrangements, which he investigates throughout the Maestà (for example, the apostles' attire in Christ's apparition in Galilee or Thomas' Incredulity [Fig. 7]), are absent here. So is the sinuous flowing line which he reserves for the garment borders belonging to the Virgin and Christ child. The greater stiffness of the figures suggests rather the ambient of Memmo di Filippuccio (Fig. 8). Nor is Duccio recorded as a fresco painter. One wonders who it was who painted for the commune the storie of the rebcllious Conte d'Elci and his son in $1311 .{ }^{24}$ The identity of the new fresco's author is best left open, although this in no way changes its clear assignation to the phase of Sienese painting corresponding to Duccio's Maestà.

22 Bellosi, "'Castrum pingatur in palatio."

23 I agree substantially (with some exceptions) with John White's views (see his Duccio, Tuscan Art and the Mediernal Workshop (London, 1979]. 193). I disagrec essentially with James Stubblebine's sectioning of the Maestì into discrete units which he assigns wholly to separate masters including not only Segna, Lgolino, the master of Città di Castello, but also Simone Martini and the Lorenzetti brothers (in Art Bulletin, Lv [1978], 185-204, and more recently in Duccio di Buoninsegna and his School (Princeton, N.J.. 1979). I. 27f.). 'This scheme surely applied to L'golino, but 10 extend it to all the above artists is unacceptable.

24 The clocuments concerning these 1 wo interesting pitture infamanti are indicated by Moran and Mallory, Burlington Magazine (April 1986). 252 n. 21.
The dating of this fresco has been sharply denied by Mallory and Moran. As stated, they give the new fresco to Simone Martini and consider the mountain hamlet to represent Arcidosso, which Simone painted in 1331. They base their identification on topographical similarities presumed to be convincing, and also on certain putative resemblances of the fortificd house on the new fresco with the fort appearing on certain scals of Arcidosso) (which they have not dated). ${ }^{25}$ I firmly disagrec. As indicated, according to style the new fresco belongs well before 133I. Nor do I find any stylistic resemblance to Simone's painting. Closer scrutiny reveals that the putative topographical resemblances hardly exist. The mountain hamlet of the new fresco is a modest affair. It rclies on nature for protection, nestled as it is on a plateau surrounded on all visible sides by a steep barren incline, with the exception of the road leading up to it at the front. Since a road normally follows the easiest approach and since it leads to the only visible gate offering access to the hamlet, it can be assumed that the terrain drops off as precipitously at the rear as it does at the front of the scenc. A wooden fence, quite similar to the one evident in the Guidoriccio fresco, surrounds the hamlet and follows the contour of the plateau. A simple wooden gate surmounted by a covered room of fers access to an open space within the village. To the right side, along a gentle incline, appear a few modest houses. In a higher location directly beyond the gate appears a modest church with a bell tower. Clearly, there is only one reasonably impressive structure within this hamlet: the fortified house that dominates the scene (Fig. 9). It is twostoricd with a tower set at the corner, projecting somewhat forward. Slit windows appear on the bottom floor while those on the upper floor are larger. The tower carries a wooden crenellated platform. The room of the main house is not crenellated. A large arched doorway containing a coffered wooden door leads onto an inner court, separated from the outer one by a wooden fence. From what is shown, we are hardly looking at a town. Instead, we observe the fortificd houscone would scarcely call it a castle - of a local lord flanked by a small church and most probably the houses belonging to his closer dependants and scrvants. 'To promote this hamlet to the status of a town or a fortification of any reasonable size does not make good sense.

How does its topography compare with Arcidosso? The latter is now a resort town of several

25 These scals are reproduced in Notizie d'Arle, Sicna (MayJune 1983), 53 figs. 3 and 4; also in News from RILA, I1 (February 1984), figure on page 11. 
thousand inhabitants ${ }^{26}$ spread over a moundshaped hill, its castle hugging the very top (Fig. 10). The ground does not fall as precipitously from the plateau on all visible sides as on the fresco, except, in some measure, towards the torrent side. As is normally the case, given the vicissitudes of warfare, of fortifications being damaged and repaired, the castle at Arcidosso consists of a patchwork of additions and alterations; their sequence and chronology remain to be defined (Fig. 11). It is now being repaired. The tower was already restored once this century. ${ }^{27}$ In its present setting the tower is not at the corner of the fort but towards the centre of its main side. Its crenellations are of stone instead of wood. This structure and the painted tower do not "mesh." This is a real castle, whereas the painted structure seems rather a fortified town house transposed into the countryside. With its corner tower it might be considered a modest version of the Bargello. The protective walls surrounding the castle at Arcidosso are no longer extant. Certain seals present the tower inside a double ring of walls. ${ }^{28}$ (Obviously, these ashlar walls are of a different structural order than the painted wooden stockade or fence. Nor is there in Arcidosso a church as closely placed to the entrance side of the castle as there is in the fresco. An attempt to draw a closer connection between the actual and painted sites on the basis of what one sees is not warranted ${ }^{29}$

We proceed to the issue of the leaning tree. Mallory and Moran have underscored that on certain seals of Arcidosso a sideward leaning tree appears within the castle's walled precinct. ${ }^{30}$ They have compared this lone tree to one they indicate as appearing beyond a wall located in back of the painted fortified house. This is not quite so. Closer scrutiny reveals not just one but, as far as I can detect (given the fresco's partial obliteration in this area), at least five trees or bushes packed close together in dense growth. They are situated not within a castle's crenellated wall, but inside a curving retaining wall rising from the rock. This retaining wall leans against the back of the building. Quite simply, we are observing here an artificial terraced garden of the kind met everywhere in

26 The Touring Club Italiano guide of Tuscany (ed. 1959, 662) lists the population of Arcidosso as 6,911.

27 The date of this restoration project, 1936, appears on the top of the tower.

28 See the scal of Arcidosso reproduced in Martindale, "The Problem of 'Guidoriccio,'" 263 fig. 13 (after Siena, Biblioteca Comunale, Ms. Fin, 17-the date of the scal is not given).

29 Scc, differently, Martindale, "l'he Problem of 'Guidoric(io)," 265 .

30 For reproductions of these seals sec Mallory and Moran, Notizie d'Arte, Sicna (May-June 1983).
Tuscany on inhabited hilly ground. To link this pleasure garden to the lone tree on Arcidosso's seals again does not make good sense.

Finally, what is known of the military action of 1331 underscores that the modest, poorly protected mountain hamlet in the fresco cannot be Arcidosso, a fortress capable of resisting a considerable army. Agnolo di Tura's chronicle offers decisive information. In 1331 the Sienese went to war against the Aldobrandeschi, counts of Santa Fiore and lords of Arcidosso. A substantial force of about four thousand men attacked them in April of that year. The Sienese took Scanzano by assault and after, following Agnolo di Tura:

They went and besicged the castle of Arcidosso, which was very strong with the strongest fortress, and for their sicge they erected two battifolli and other structures for throwing stone, and they occupied the passes and the ravines so that no one could assist Arcidosso, and continuing ... the sicge ..., after many battles, [since] the castle was strong and well supplied, they decided to mine below the ground; and so they did. The counts, realizing that they alone could not protect it from the force of the Sienese, asked help from the grandson of King John, who was in Lombardy at Brescia, who sent them two hundred cavalry. In that moment the Sicnesc took the castlc of Arcidosso by means of this tunnel, penctrating inside with great battle on the twelfth of August and many died from within and without ....31

The siege of Arcidosso was a substantial military operation. It was planned to last a long time, although after four months it was concluded by direct assault. The Sienese erected there two battifolli, whereas at Montemassi, it will be recalled, they were content with just one. This information does not jibe with the painted hamlet. A fortified house is not a castle. To take this hamlet the Sienese would hardly have needed a force of thousands of men, two battifolli, and artillery. Last

31 "E poi andaro ad assedio al castcllo d'Arcidosso, molto fortc co'la rocha fortissima, c assediato vi fèro duc battifolli e altri difitii da gittare dentro pictre, c prescro i passi e a'fossati in modo che socorso non potessero avere, e continuando i Sanesi l'assedio al detto castello d'Arcidosso, continuando molte battaglic, el castello era forte c ben fornito, deliveroro di farvi una cava sottcra; c così fèro. I conti veduto che per loro non potealo riparare a la forza de'Sanesi mandaro per aiuto al figliuolo de're Giovanni, ch'avea lassato in Lonbardia a Brescia, il quale li mando 200 cavalieri. In questo stante i Sancsi ebero il detto castello d'Arcidosso si per la detta cava che v'entroro dentro a di 12 d'Agosto con grande battaglia, c morivi di molta gente di dentro e di fuore. In Siena sc fé gran festa di di c di notee, facendo falò duc scre" (chronicle of Agnolo di Tura, in L. A. Muratori, Rerum italicarum scriptores, cronache senesi, $\mathrm{xv}, 6$, sects. 5 and 6 , ed. $A$. Lisini and $F$. Iacometti [Bologna, 19.35], 503). Max Seidel has confirmed the reliability of $A$ gnolo di Tura's account of the taking of Arcidosso by excavating a tunnel with reference to pertinent archival documentation ("'Castrum pingatur in palatio,," 29r.). 
but not least, there is nothing in the fresco to indicate military violence. There are no weapons, other than the sword worn by one of the two men standing at the left of the landscape, which surely formed part of his official attire. The submission of this mountain hamlet involves a peaceful act. All entrances-leading through the two wooden fences and into the fortified house-are open. There is no trace of a besieging force. There are no stone walls to be mined. The Arcidosso thesis must be discarded.

\section{'THE GUIDORICCIO FRESCO: DESCRIPTION' AND SIYYLE (FIG. 12)}

The fresco, in the shape of an oblong rectangle, occupies the full width of the upper third of its wall. A wavelike rhythm prevails, following the plane of the wall. This rhythm follows the contour of the hills in the distance and of the horse, which strides parallel to the picture plane. The equestrian group stands on the base line in strict profile, at the centre of the pictorial field, so that the head and torso of the rider connect with the vertical axis. The individual forms are painted in considerable relief. A two-dimensional effect predominates, however, in the extended silhouette of the landscape and its architecture, and also of the horse's head and the rider's upper body, all set before the blue sky. The landscape evolves in its wavelike lateral rhythmic contour, alternately cresting and dipping, descending leftward from the mountain at the right and terminating in the incline at the lower left corner. (There is good reason to assume, as we will see, that the repainted town of Montemassi and landscape at the left side follow the original design.) The face of the rider is curned in the direction of the hill town, towards which the horse is moving. Spatially and formally the equestrian group is detached (though not completely) from the landscape. It stands on the base line and thus follows the picture plane, while the landscape in back of it rises along varying tilting ground planes into the distance. Movement into the landscape is carefully controlled by means of slanting, gently broken rock formations and a wooden fence which meanders over the irregular ground. It breaks into the picture just before the horse and rises gently leftward. A centred vantage point on the part of the beholder seems to be assumed, in spite of the fresco's elevated location. The battifolle as well as the cavaliere are seen en face, whereas Montemassi seems observed from a somewhat lower vantage point, and the Sienese camp in the lower right corner is seen from above.

The predominant silhouette of the landscape is modified by the partial emergence of objects in the distance beyond the outline of hills, these being the fence before the horse's chest, including just a bit of the fort's crenellated wall slanting sharply into the distance, and the tents to the right of the battifolle. Accordingly, the military landscape is understood in three dimensions, with the wooden siege fence surrounding the fort and connecting it to the Sienese camp. A strange surrealistic quiet, virtually anticipating (Giorgio di Chirico's empty cityscapes, envelops this siege which is void of men, with but their lances, banners, and shields leaning against the fence from within. The fierce actions and emotions of war are frozen here into a ritual silence. As a consequence, the central rider is formalized and magnified. Besides his centred location and considerable scale, he is so set in front of a valley that he and the horse's head are fully projected before the sky. His presence is further underscored by the rectilinear disposition of his profiled head and glance, thus arresting the composition's curvilinear flow at the very centre. Horseman, hill tow'n, fortress, and military camp are distributed over the landscape separately, covering more or less equal ground. As a consequence, neither horseman nor any of the other principal elements predominates. The landscape is as important as the rider. The general character of this composition offers a clear combination, in the painter's mind, of separate themes referring together to an actual military action: the siege at Montemassi, and the glorification of Siena's military might represented by the equestrian portrait of its general and by the strange fortress in the shape of a towered, crenellated, walled precinct that contains a catapult, generally referred to as the battifolle. One gains the impression, to be more fully explored, of a remarkable "rhetorical" mind at work. Topographical reference to the siege is contained, reduced to essentials. Attention is focused on the equestrian general: the representative of Siena's power.

The gencral is Guidoriccio da Fogliano. ${ }^{32}$ The coat-of-arms on the horse's gualdrappa and on the rider's cloak, which appear also on a banner rising above the battifolle, belongs to the Da Fogliano family. Essentially the same coat-of-arms, comprising a tilted line of black diamonds set against a yellow ground covered with grape leaves, appears on the family's coat-of-arms in Reggio Emilia, its place of origin. ${ }^{33}$

32 Moran had originally denied this (Paragone, xxvıII, 333 [November 1977]), considering that had Guidoriccio been portrayed his image would have been removed from the wall following his dismissal, supposedly in disgrace, as general of the Sienese forces in 1333.

33 Concerning the Da Fogliano coat-of-arms see Polzer, "Simone Martini's Guidoriccio da Fogliano," 109ff.; also Litta, Famiglie celebri italiane. 
The siege represented on the fresco is the one of Montemassi. It occurred in 1328, the date evident below the rider at the centre of the lower border. ${ }^{34}$ Two structures depicted at the right side of the fort can still be seen at Montemassi today (Fig. 13). They belong to a restored portion of the fresco, but it can be assumed that the restored image of the fort copied the original one.

The landscape setting, seen from the east, refers to the siege as well (Fig. 14). ${ }^{35}$ The mountain to the right side with the Sienese encampment on top and below is surely Poggio Colombo. The hill with the turreted, walled precinct, the so-called battifolle, is most probably the one where the cemetery is now located, a short distance to the north of Montemassi. ${ }^{36}$

We are not presented here with an optically precise, comprehensive vantage point. For this to enter the painter's artistic vocabulary, one has to look ahead into the quattrocento. Simone simplified the actual topography as he strove to create an effective statement of military triumph. It is appropriate to note here that even Ambrogio Lorenzetti's exemplary landscape and cityscape from his Good Government fresco, which reaches from Siena's cathedral all the way to Telamon and the sea, ${ }^{37}$ hardly aims at detailed topographic precision but at a persuasive general impression of Siena and its territory.

We now proceed to the primary issue: does the Guidoriccio fresco's style agrec with that of Simone Martini? I am convinced it does. ${ }^{38}$ ' 1 he fluidity and certainty of the drawing is of the highest quality throughout. Witness in particular the red contour drawing of the equestrian group. The original luxurious presentation in simulated gold and silver of the horse's and rider's dress (see below) conforms both in concept and technique to Simone's remarkable concern for precious surfaces complexly evident in his Palarıo Publico Maestà, his remarkable Saint Louis panel in Naples and the Annunciation of 1333, which he painted together with his brother-in-law Lippo Memmi. Indeed, in the luxurious treatment of surfaces Simone remains unexcelled among his proto-Renaissance peers. Among particular resemblances to his

34 The central portion of the date-hall of the first " $\mathrm{I}$ " and the "mac::"-is modern.

35 Sec also Uta Feldges, Landschaft als topographisches Porträt (Bern, 1980), 142f.

36 See also Martindale, "The Problem of 'Guidoriccio,", 262 n. 35).

37 Both the cathedral and Telamon belong to areas which have been repainted so that thcir original presence is uncertain, but this hardly changes the effective generalized Sienese character of the painted landscape.

38 See Bellosi, "'Castrum pingatur in palatio,' " j2ff.; Polzer, "Simone Martini’s Guidoriccio da Fogliano," passim, esp. $113 \mathrm{ff}$. autograph paintings, one notes the barrenness of the beige hills, which return in the landscape from the Assisiate Saint Martin Renouncing his Arms (Fig. 15), and the side scencs of the Sant'Agostino Novello altarpiece in Siena (Fig. 16). There is also the horse - its wavy tail, the position and shape of the legs, the hooves, down to the pattern of the nails holding the shoes in place, shoes with identical tiny lower rear plates - all this corresponding to Saint Martin's horse in Assisi (Fig. 17). Observe the equally decisive definition with few bold lines of the respective physiognomies of Guidoriccio's head (Fig. 18) and the portrait of Cardinal Gentile Partino da Montefiore at Assisi (Fig. 19). Consider the virtual identity of the Huns' encampment at Assisi (Fig. 15) with that of the Sienese before Montemassi. Exempla gratia! I find especially striking the similar brushwork and shaping of Guidoriccio's hands and lingers (Fig. 20) with those at Assisi; note one from the scene of Saint Martin Meditating (Fig. 21). The pattern of cross strokes used to model the thumb is virtually identical. These detailed resemblances, in my "Morellian" perspective, approach the near certainty of matching fingerprints; collectively, they cannot be denied. Nor is this all. Equally persuasive is the particular textured treatment of the pictorial surface by the application of motif punches on the garments and armour of the equestrian group. To my knowledge, their application on garments both in fresco and panel painting is restricted, with rare exceptions, to Simone Martini and close associates-Lippo Memmi and "Barna," who is surely Lippo's brother ' $\Gamma$ ederigo ${ }^{39}{ }^{3}$ Simone Martini preferred the type of punch consisting of a rectilinear pattern of reverse pyramids, which he used to texture the rider's cloak and the horse's gualdrappa (Figs. 22-23). ${ }^{40}$ It is already found, similar in size though not identical, on the lower border medallions from the Siena Maestà (Fig. 24), at the opposite side of the Sala del Mappamondo. The same type of punch in smaller scale appears on the Saint Louis panel in Naples. It is also used in various sizes on his Assisi frescoes, on haloes, and the representation of cloth. ${ }^{41}$ The use of tiny punches

39) In recent years there has been an attempt to integratc "Barna" and Lippo Memmi into one person. Sec, most recently, Gaudenz Freuler, "Lippo Memmi's New 'lestament Cycle in the Collegiata in S. Gimignano," Arle Cristiana, Dccxur (1986), 9311:; also Antonino Caleca, "Tre polittici di Lippo Memmi. Un ipotesi sul Barna c la bottega di Simone e Lippo," Critica d'Arte, xuI (1976), 49-59, and Xı.II (1977), 55-80. I shall elaborate on the Barna-Tederige issue under separate cover.

4 () Polzer. "Simonc Martini's Guidoriccio da Fogliano," $117 \mathrm{ft}$. A more extended study of Simone's punchwork is in progress.

41 Small punches used for texturing cloth already appcar on the Siena Maestì, for example, on the Christ child's clress. 
to texture armour is also found in "Barna's" San Gimignanese Crucifixion (Fig. 25). Mallory and Moran have dismissed these remarkable correspondences in ornamental practice, insisting that these punches could be casily copied. To this end they obtained punches from modern restorers used to duplicate ancient ones. To my knowledge, and upon checking with collcagues who have considerable experience with trecento punched ornament, ${ }^{42}$ examples of pertinent modern loolthc-expert duplication are extremely rare. I suppose that, as in successful counterfeiting, with sufficient effort such punches could be reasonably closely imitated. Shifting the scene from punched ornament to cosmetic restoration, which may serve as a convenient parallel, I have become all too aware in time of how the first-rate restorer can fool the expert's eyc regarding what in a painting is original and what is restored without the laboratory's assistance. However, all this does not obviate the fact that whoever believes in the fresco's later production should account for the uniqueness of this specific type of punched ornament, which is restricted to the oeuvre of Simone Martini and his closer circle, and should identify an appropriate later historical setting in which retrospective imitation would have been carried to this extreme detail-hardly necessary in a fresco so distant from the observer.

\section{I'ECIINIC:AL (ONSIDERATIONS}

The hill town at the left side of the Guidoriccio fresco (Fig. 26) is not original. Because of water clamage this portion of the fresco was repainted, probably quite early. ${ }^{43}$ The repainted portion of

42 Information obtained by letter from Norman Muller, Mojmir Frinta, Erling Skaug.

43 Tintori places this repainting toward the later trecento, as indicated by his technical report available at the library of the Kunsthistorisclies Institut in Florence, 11, and also verbal information. Surely, this repainting was brought about by the same penetration of humidity which caused the lateral sections of Ambrogio Lorenzetti's landscape and cityscape painted on the opposite side of the same wall to deteriorate as well. The left side of Ambrogio's city was repainted already in the later trecento. Cesare Brandi assigned this repainting to lippo Vanni (in Bollettino d'Arte, XL [1955], 119-23), whereas Luciano Bellosi (Buffalmacco e il Trionfo della Morte [Turin, 1974], 53f.) and Alberto Cornice (in Gotico a Siena. Miniature, pilture, oreficerie, oggetti d'arte. Ciatalogo della mostra, Siena, Palazzo Pubblico, July 24-()ctober 30, 1982, 288) assign this restoration, convincingly, to Andrea Vanni. The repainted portion at the right side of Ambrogio's landscape, corresponding roughly to the location of Montemassi on the opposite side of the wall, probably belongs to the hand of Pietro di Francesco degli Orioli who worked in the Sala della Pace in 1491 whon he was paid 65 lire "per dipentura e acconcimi" (sec Borghini, in Palazzo) Pubblico di Siena, 210) figs. 262 and 266, 482 document number 395 ). the Guidoriccio fresco reveals a style consciously imitating the original one, although of obviously lesser refinement. The rough seam separating the repainted from the original portion is clearly visible, even from the floor.

Some original preparatory marks assisting in the formation of the composition are evident: plumb lines indicating the central vertical axis and some vertical lines of the towers of the battifolle (Fig. 27), and some indented lines following the contours of the tents. The equestrian figure (Fig. 22) was initially outlined in red. The painting is essentially done in truc fresco, with the addition in secco, as customary, of the azurite of the sky. The armour and the grapc leaves on the garments of the horse and rider were covered with tin leaf, of which only small fragments remain. The tin initated silver. The present green colour of the grape leaves is not original, and was surely applied in the erroneous belief that the green preparation on the leaves below the tin leal, which emerged as the tin flaked off, represented their original colour. Set against the yellow ground worked in relief, these garments originally appeared to be inade of silver and gold. ${ }^{44}$ The original effect of this luxurious attire of the equestrian group must have been striking incleed. This usc of tin leafintended to create the effect of precious materials, and also to cover armature - is widcly recorded in the oeuvre of Simonc, and also of Lippo and "Barna." It formed a key part of the extraordinary manner in which Simone Martini obtained detailed luxurious effects in mural painting. ${ }^{45}$ This multimedia approach, together with the elaboration of the motif punch, represented a Sienese chapter of the "aristocratic" style of mural decoration which evolved at the time in the gothic North,

44 Gavazi, technical report avalable at the library of the Kunsthistorisches Institut in Florence, no pagination: " . . si stabiliva di fare: delle: analisi su prelicvi effetcuati sulle foglie e sulla armatura (lel cavaliere, in quanto con la lente: apparivano piccolissimi frammenti che facevano pensare all'antica presenza di un mctallo. Queste analisi ci rivelarono che si trattava di stagno. La caduta (lello stagno) aveva in passato scoperto un vercle di preparazione a buon fresco tanto da inclurre in errore i restauratori precedenti i quali avevano ritenuto che le foglic fossero sempre state verdi e quindi le avevano tutte ripassatc. Si perdeva cosi un effetto che in origine doveva presentare le foglic in metallo chiaro su di un fondo giallo nel quale la bulinatura a stampino doveva creare un effetto oro."

15 See I.conetro Tintori, "Relazione tecnica sulla Maestà di I.ippo Memmi nel Palaro (ivico di S. Cimignano," typescript (Florence, 20) Deccmber 198()), 4 ; Leonctto Tintori, "Golden I"in' in Siencsc Murals of the Early Trecento," Burlington Magazine (1982), 94f ; I conetto Tintori, "Segualazioni sul costante progresso tecnico nelle pitture murali di Simone Martini," paper presented at the symposium, Studies on ltalian Mural Techniques in the Renaissance, held at Villa I I attion 23-24 May 1983, to be published in the acts of the symposium. 
equally stressing luxurious materials and detailed ornament applied in relief. ${ }^{46}$

Given the fresco's large size, the limited number of giornate is striking. Tintori originally identified nine, but Gavazzi reduced this number to six, excluding the repainted portion at the left side. He underscored that the large space of these giornate is exceptional in the trecento, as well as the hurried application of the plaster (la stesura frettolosa: more about it below). Prussian blue was applied over the sky relatively recently. ${ }^{47}$

The large, roughly triangular section of plaster covering the upper right corner of the fresco and extending leftward for about three metres belongs, according to Tintori, to an earlier fresco (Fig. 28). He states that the little original colour belonging to it is unclear, covered by a grey ground which served as a preparation for the azurite of the sky of the Guidoriccio fresco. Sketched on this grey ground are two loosely indicated standards which resemble those surmounting the battifolle with the exception of their excessive size. Tintori also links certain remains of a military encampment on the mountain to the earlier fresco. ${ }^{48}$

46 Concerning the "aristocratic" style of mural painting in northern Furope see, recently, P. Philippot in P. and L. Mora and P. Philippot, Conservation of Wall Paintings (London, etc., 1984), 124ff.; also P. Philippot, "Les techniques de peinture murale au Nord des Alpes aux xvr" et $\mathrm{XV}^{\prime \prime}$ siècles et leurs rapports avec les courants stylistiques: Etat des connaissances et propositions pour la recherche," Atti del XXIV Congresso Internazionale di Storia dell'Arte, Bologna, Settembre 10 all 8, 1979. La pittura nel XI' e XI'secolo. Il contribute dell'analisia tecnica alla storia dell'arte (Bologna, 1983), III, 73-91

47 This could have been done at the time when Pompeo I itta had the frescocleaned in connection with the preparation of the genealogical table of the Da Fogliano family for his Famiglie celebri italiane. On pl. 1, which bears the clate 1834 , he refers to the cleaning of the Guidoriccio fresco and the well-preserved condition of the colour. From this restoration project could date the green repainting of the garments' grape leaves.

48 Leonetto 'Tintori, "Seconda ricognizione," typescript, $2 \mathrm{f}$.: "Questo grande frammento di intonaco, un triangolo irregolare alto due metri che si protende a sinistra per circa tre metri, conserva poche tracce dei colori appartenenti alla pitture più antica e questi sono confusi e coperti da una tinta grigia data quale preparazione per l'azzurite del fondo del 'Cavalicre.' Su questo grigio esistono, tracciati rapidamente con un grigio un po più chiaro, due vessilli molto simili a quelli adottati per coronare le torri del 'Battifolle': soltanto sono assi più grandi e di una proporzione impossibile per decorare delle torri incluse nella scena. Per questo dovrcbbero essere considerati quali escmpi destinati ad essere coperti dal colore finale del fondo.

"Assai più importanti sono invece i resti di un accampamento militare in alto sul colle ed i tetti di clue tende minori inclusi nell'accampamento dipinto sull'intonaco nuovo. Questi avanzi di vecchia pittura si distinguono dal nuovo per l'uso di un colore diverso e per l'espressione dei tratti assai più forti e semplici.

"A sostegno dell'ipotesi che attribuisce l'appartenza di questo intonaco alla pittura precedente, precedente anche
Since the fresco was painted from right to left and from the top on down, this information would indicate that when it was begun in the upper right area the painter did not bother to apply a fresh layer of plaster - an exceptional way of proceeding. Of course, since this portion of the fresco was to be covered in secco by the azurite of the sky no one would have been the wiser. Prior to the application of the azurite and the actual painting of the fresco, the painter would have made some preliminary drawings of the intended subject matter on the pre-existent plaster. At the time the intended composition may not as yet have been clear in his mind. This would explain the resemblance of the loosely drawn elements to those finally painted as well as certain differences in scale and treatment. Altogether, this exceptional procedure would indicate that the fresco was painted in great haste. Since the painting proceeded from right to left, typical of a left-handed painter and in keeping with Simone's procedure on the Siena Maestà and the frescoes in the Saint Martin Chapel, ${ }^{49}$ he used the pre-existent plaster at the very beginning of his work on this fresco, and for just a limited space. Plausibly, the remainder of this earlier fresco is sandwiched beneath the Guidoriccio. This is indicated as well by ultrasonic tests made some years ago. ${ }^{50}$ These findings could be confirmed by the extraction of small core samples from unobtrusive places.

Certain marks on the fresco have a direct bearing on its dating. In 1345, Ambrogio Lorenzetti's famous round Mappamondo, painted on wood, was mounted on the wall below the Guidoriccio fresco. ${ }^{51}$ The circular grooves left on the wall by its rotation are perfectly visible. The uppermost grooves extend over the lower border of the frescoso that the Mappamondo would have covered the date of 1328. A slight shift in the concentricity of these grooved lines would indicate, as Max Seidel has carefully noted ${ }^{52}$ that the location of the pivot connecting the Mappamondo to the wall and supporting and

a quella della 'Resa' [the new fresco below the Guidoriccio], esiste il fatto che l'azzurite del fondo qui si é comportata in modo diverso da quella stesa sull'intonaco nuovo, dove ha potuto usufruire dell'ausilio della carbonatazione della calce non perfettamente secca come quella del vecchio intonaco."

49 Tintori, technical report available at the library of the Kunsthistorisches Institut in Florence, 11-16.

50 These ultrasonic tests were carried out by the firm of E.DI.T T.CH of Florence.

51 Concerning Ambrogio Lorenzetti's Mappamondo see conveniently Edna Carter-Southard, "'The Frescoes in Siena's Palazzo Pubblico 1289-1539: Studies in Imagery and Relations to Other Communal Palaces in Tuscany," Ph. D. Dissertation, Indiana University, June 1979 (New York and London, 1979), 237-41; also Borghini, in Palazzo Pubblico di Siena. 223f.

52 Seidel, "'Castrum pingatur in palatio,", $22 f$. figs. 4 and 10. 
controlling its rotation was slightly shifted, surely with the intention that it not extend over the Guidoriccio fresco's lower border and its date. Another chronological indicator is Sodoma's frescoes of Saint Victor and Saint Ansanus appearing at the lower sides of the same wall. They clearly extend above the Guidoriccio fresco..$^{53} \mathrm{He}$ painted them in 1529. At about the time they were painted, the Mappamondo was reduced in size so that it should not extend over Sodoma's Saints.

We now come to a significant unresolved problem. At the right corner of the wall, the Guidoriccio fresco connects with Lippo Vanni's Battle in the Val di Chiana. Lippo's fresco is signed and dated 1363. The respective walls supporting these frescoes have separated in time. This area of separation was examined by Giuseppe Gavazzi, who states that at one small point the intonaco of the Guidoriccio fresco leans over the one painted by Lippo Vanni. Obviously, this observation is of the greatest significance here, and for this reason I quote Gavazzi:

The question of the attachment of the plaster of Guidoriccio and that belonging to Lippo Vanni (in the right corner as one observes the wall) is best left open. However, in good conscience we signal that the Guidoriccio fresco seems to rest on top of Lippo Vanni's wall. Unfortunately the absolute clarity is compromised by an ancient fall of the plaster at the extreme edge precisely at their juncture. Only in one point a small fragment of plaster belonging to Guidoriccio laps over the plaster painted by Lippo Vanni. ${ }^{54}$

If Gavazzi is correct, then obviously the Guidoriccio fresco cannot be by Simone Martini since it would postdate Lippo Vanni's fresco and by 1363 Simone was long dead. Given the importance of Gavazzi's observation, it is indeed unfortunate that the matter was not more carefully examined before this aperture was closed. Here we have conflicting evidence. Obviously the Guidoriccio fresco cannot both precede Ambrogio's Mappamondo ${ }^{55}$

53 See the technical reports of both Gavazzi and Tintori, as in note 16 .

54 Gavazzi, technical report, no pagination: "Come a perto si deve lasciare il discorso riguardo all'attaccatura dell'intonaco del Guidoriccio e quello del Lippo Vanni (angolo destra per chi guarda la paretc). In coscienza dobbiamo pero segnalare che l'affresco del Guidoriccio sembra sovrammetersi agli intonaci della parete da Lippo Vanni. Purtroppo la chiarezza assoluta é compromessa da una antica caduta degli intonaci al loro estremo margine, nel punto esatto in cui si sarebbe dovuti incontrare. Solo in un punto un piccolo trammento di intonaco del Guidoriccio si sovrapponeva all'intonaco dipinto da Lippo Vanni,"

55 Gordon Moran tried to find a way around this dilemma by proposing that Ambrogio's Mappamondo was a small mobile object once located in the Sala dei Nove, rather than the large mobile disk in the hall which still carries its name (in Notizie d'Arte, Siena [February 1982], 52). This is not acceptable. The many references to the Mappamondo as a and postdate Lippo Vanni's Battle in the Val di Chiana. Given this problem, I proposed one year prior to the Simone Martini congress (which took place in Siena in March of 1985) that the juncture of these two frescoes should be thoroughly examined by an expert impartial party. ${ }^{56}$ This still remains to be done. At this time I have no choice but to accept the evidence I have observed with my own eyes: the impression which the rotation of the Mappamondo has left on the Guidoriccio fresco, together with all the other evidence previously given. In addition to the fresco's style and ornamental technique, I also find that it conforms substantially to what is known of the siege and to the propagandistic role of the kind of triumphal painting it represented in a Tuscan commune.

The reader should take note of the following information that has just been obtained from Giuseppe Gavazzi:

1. Comparison of the pictorial technique of the Guidoriccio fresco and the one recently discovered below reveals that the Guidoriccio was painted, as stated, in true fresco except for the azurite sky and the leaves on the rider's cloak and the horse's gualdrappa, which were originally covered with tin (surely treated to give the appearance of precious metal). The intonaco of this fresco is rough and the colour is thickly applied. On the other hand, the recently discovered fresco's intonaco is smooth and the colour is thinly applied in successive layers. Only the faces are in tempera; real gold was applied on the belt buckle and the sword handle of the principal figure.

2. Concerning whether there was a fresco beneath the Guidoriccio, Gavazzi removed tiny portions of the Guidoriccio fresco from various areas about one month before the Simone Martini congress in March 1985, in order to observe directly what existed below. He found that the fresco adheres directly to the brick wall, and that there exists a sinopia for the equestrian group.

3. The examination of the corner of the walls connecting the Guidoriccio with the Lippo Vanni remains to be done. Gavazzi still believes, as before, that the Vanni fresco predates the Guidoriccio. The pertinent connections and superpositions of plaster layers are a complicated matter. The intonaco of the Lippo Vanni fresco does not, according to Gavazzi, extend all the way to the

substantial object familiar to all Sienese cannot be discounted. The extensive restoration of it carried out by Bartolo di Fredi, Cristofano di Bindoccio and Meo di Pietro in 1393, involving substantial expense for colours, points towards larger size. For relevant documentation see Carter-Southard, "The Frescoes in Siena's Palazzo Pubblico," and Borghini, in Palazzo Pubblico di Siena.

56 Polzer, "Simone Martini's Guidoriccio Fresco in Siena." 
brick wall that supports the Guidoriccio. A layer of different plaster intervenes and this one differs from the ariccio and intonaco of the Guidoriccio fresco. This complex situation further underscores the need for careful re-examination of the area.

\section{IHE SIEGE AT MONTEMASSI AND OBSERVATIONS CONCERNING CONTLMPORARY SIEGF WARIARE IN TLSC:ANY}

The fort at Montemassi stands at the side of the western coastal mountain range where it turns some distance towards the interior. Securcly anchored on a high rock, it overlooks the plain of the Maremma stretching southward towards Grosseto. Strategically it was one of a series of forts set along the western flank of the Sienese territory not far from the coastal road which led from Pisa to Rome.

In December of 1327 the Cappucciani, feudal lords of Montemassi who had sworn loyalty to the Sienese republic in 1324, rebelled. This rebellion represented a particular instance of local resistance to the general trend of the powerful late medieval Tuscan communes extending their sway over the surrounding territories. Specifically, the Montemassi rebellion was triggered by the change in the constellation of power in 'Tuscany brought about by the descent in 1327 of the German emperor Ludwig the Bavarian into Italy. It was hardly a coincidence that the lords of Montemassi rebelled just as Ludwig's army crossed the Maremma on the way to Rome during the winter of 1328. The principal instigator of this rebellion was Castruccio Castracani, Lord of Lucca, an outstanding military leader who dominated the military scene in Tuscany after his decisive victory over the Florentines and their Guelph allies at Altopascio in 1324. Giovanni Villani refers unequivocally to his instigation and backing of the rebellion. ${ }^{57}$ The Sienese could not accept this challenge

57 Giovanni Villani, Cronaca, x, 80: "Nel detto anno, a di 10 d'Aprile, (astruccio prima fatto rubellare, c poi il fece fornire, Montemassi in Maremma, il quale certi gentili uomini Maremmani, che v'aveano ragione, col lavore di Castruccio l'aveano rubellato a dispetto de'Sancsi che v'erano ad oste, e con battifolle, e'Fiorentini vi mandarono vi loro soccorso ducentocinquanta cavalieri; ma giunsono tardi sicchè non poterono riparare alla forza della cavalleria di (astruccio. Per la qual cosa i sanesi mandarono ambasciadori a Pisa a (astruccio a domandargli che non travagliasse contro a loro. Castrucio per ischernie de'Sanesi, non fece loro mull'altra riposta, se non per una lettera bianca, ch'altro non clisse se non levate via chechello, in sanesc, cioe il battifolle; onde i Sanesi forte ingrecaro e rinfortami l'assedio coll'aiuto de'liorentini..." See also Agnolo di Tura, in Muratori, Rerum italicarum scriptores, cronache senesi, 47(). (alstruccio's biography is consiclered passively, since this would have invited further rebellions among their subject forts and towns. The Sienese army arrived at Montemassi on 21 January $1328 .{ }^{58}$ After studying the site, Guidoriccio decided that the fort was impervious or too costly to take by assault, and he decided on a siege which was to last over seven months. The Sienese proceeded immediately to erect a battifolle. According to Lisini and Iacometti, it was completed in just thirty-nine days. Romagnoli writes that it was designed by none other than Lando di Pietro. Lisini and Iacometti consider Guido di Pace to have been the architect charged with this project, whercas Romagnoli writes that he served under Lando di Pietro. ${ }^{59}$ This battifolle was an elaborate structure. It was certainly not a siege tower of the type that was often used in direct assault, moved forward and connected to the besieged walls. The sharply slanting terrain at Montemassi would have excluded its effective use. This battifolle was erected with a prolonged siege in mind. What was its intended role and what did it look like?

Assault towers of the mobile type were frequently used in medieval siege warfare. They played a decisive role in the capture of Jerusalem during the first crusade. ${ }^{60}$ They consisted of a wooden truss supporting a protected platform which rose above the defending walls against which they were rolled. They appear in a consistent form in medieval works of art ${ }^{61}$ One observes

reccntly by Michele L, ur.7ati in the Dizionario biografico degli italiani, xxı (Romc, 1979), 200-10.

58 Agnolo di Tura, in Muratori, Rerum italicarum scriptores, cronache senesi, 464.

59 F. Iacometti and $\Lambda$. I.isini, in Muratori, Rerum italicarum scriptores, cronache senesi, 464 n. 1; E. Romagnoli, Biografia de'bellartisti senesi, 11 (1876; 1976 reprint), 74 and 274. The gathering and publication of all awalable archival evidence concerning Montcmassi's battifolle could well contributc to the understanding of its military role.

60 Steven Runciman, History of the Crusades (Cambridge, 1951), I, 282; also Charles Oman, A History of Wor in the Middle Ages (ed. 1924), 1, 134 f., 11, 49.

61 Such an assault tower appears in Bernard de Montfaucon's drawing of the stained glass medallion firom the crusader window once in the abbcy church of Saint Denis representing the concuest of Jerusalem (reproduced in Les momumens de la monarchie française. . . [Paris, 1729-3.3], 1, pl. 2); see also the Siege of Calais and the Attack on a Dungeon in the Castle of Emmaus in William of 'Tyre's Histoire de Jerusalem in the Bibliotheque Nationale in Paris (reproduced in Hannsjodhim W. J. Koch, Medieval Warfare [New York, 1978], 80 and 87, precise identification of and pagination in manuscript not given). (Cola di Ricnzo used such assault towers in his attack on Marino's citadel in 1347: "To take the tower by storm he had two wooden castles built, which rolled on whecls and were equipped with ladders and wooden towers. You have ncver seen such clever clevices (The Anonjmous life of Cola di Rienzo, trans. John Wright [Toronto, 1975], Book 1, chapter 31, 79). 
such towers on the relief of the capitulation of Chiusi (Fig. 29) on Guido Tarlati's tomb monument in Arezzo Cathedral, which is roughly contemporary with our fresco. One would like to know what the wooden battifolli erected by the Sienese at Elci during the hostilities of 1311-15 were like. ${ }^{62}$ The battifolle at Montemassi was surely of a different type since it also offered protection. During the siege Castruccio sent to Montemassi a substantial force of four hundred men, both cavalry and infantry, on 10 April. The Sienesethey may have been caught with insufficient troops at just that moment - retreated to nearby towns under their control: Roccastrada, Montepescali, and others. However, "the battifolle was left staffed with men and supplies." ${ }^{33}$ Castruccio's forces entered the besieged fort. They looked after its defences and evacuated the women. They left shortly after for Pistoia, a much more significant military objective, which had fallen to the Florentines. ${ }^{64}$

From this account it is evident that the battifolle at Montemassi had a substantial defensive capability. Surely this would have applied as well to battifolli serving other sieges. Accordingly, the battifolle served in different roles. The one at Montemassi was also used for quartering troops, ${ }^{65}$ and, as has been seen, for storage. It stands to reason that it served for stationing artillery: witness the catapult inside the towered fort on the Guidoriccio fresco. One is tempted to suppose that it also served as headquarters. The erection of such multipurpose structures at sieges would respond to the uncertainties of military fortunes. Their rapid erection at the beginning of sieges surely involved a high level of military and engineering knowledge. An exceptional contemporary example of elaborate defensive arrangements used by a besieging army, comprising battifolli, elicited the highest praise from the chronicler. Giovanni Villani wrote of Castruccio's siege of Pistoia: "He wholly surrounded the city with his army and battifolli, so that no one could leave or enter, blocking the roads

62 Mallory and Moran (Burlington Magazine [ $\Lambda$ pril 1986], 250: Siena, Biblioteca Comunale, Ms. A. vir. 16, 6f ): "pagano cinclue maestri di legname, quali dovevano andare a fare i batifolle a Elci."

63 "Lassaro il battifolle fornito di gente e di vettovagl[i]a" (Agnolo cli Tura, in Muratori, Rerum italicarum scriptores, cronache senesi, 470).

64 Agnolo di Tiura, in Muratori, Rerum italicarum scriptores, cronache senesi, 470; also Giovanni Villani, Cronara, x, 80 .

65 Uta Fedges-Henning writes that "in den zahlreichen Belagen über die Belagerung von Montemassi die Soldaten nic anders als zur 'Battifolle von Montemassi' geschickt (wurden). Vgl. Biccherna 157, Uscita dello scrittore, 1328 Jan.-Juni, und Biccherna 393, Memoriale 1328. Jan.-Juni" (Mitteilungen des Kunsthistorischen Institutes in Florenz, xvı [1973], 276 n. 18). and making ditches, obstructions and pale fences of marvelous workmanship, so that no one could leave Pistoia, nor could the Florentines attack his army from any direction on the outside." ${ }^{\prime 66}$ Agnolo di Tura echoed Villani's praise: "And know that this enterprise cost a great deal and caused disgrace and damage to the Florentines: it is virtually incredible that Castruccio should besiege Pistoia with 1600 cavalry. And the Florentines had more than 3000 with much infantry, and they could not remove them." ${ }^{7} 7$ The Florentines had to withdraw and Pistoia submitted to Castruccio "a patti," that is, according to terms of capitulation agreed upon by both parties. This type of conclusion to siege warfare was then quite common. The aim of war was not the annihilation of the enemy, but rather absorbing the defeated within the victor's sphere of power.

During the same year, 1328, there took place another long siege in Tuscany: of Borgo San Sepolcro, strongly fortified "by both walls and ditches," and there too Guido Tarlati, the attacker, erected a number of battifolli. After eight months this siege was also concluded $a$ patti. ${ }^{68}$ (Of course, long sieges were expensive: witness the cost of the siege of Montemassi estimated as equalling approximately the entire normal year's budget of the state of Siena. ${ }^{69}$ Hence, when possible, direct assault was preferred. Accordingly, the Florentines captured Pistoia in a surprise night attack under the leadership of Filippo di Sangineto. ${ }^{70}$ The same general took the Pisan fortress of Carmignano by direct assault. ${ }^{71}$ And Guidoriccio took Arcidosso in 1331 by mining under its walls although, initially preparing for a long siege, he had erected there two battifolli. ${ }^{72}$ Examples can be extended. Of course, as indicated by their presence on the relief of the capitulation of Chiusi on the Tarlati tomb (Fig. 29), wooden assault towers of the traditional mobile type continued to be used.

66 "... Egli cinse la città d'intorno intorno di sua oste e con più battifolli, sicchè nullo vi potea entratc ne uscire, avendo tagliate le vie $e$ fatti i fossi e isbarre e steccati di maravigliosa opera, acciochè nullo potesse uscire di Pistoia, ne c Fiorentini impedire ne assalire sua oste da niuna parte di fuori" (Giovanni Villani, Cronaca, x, 84 and 85).

67 "E sapi che questa inpresa fù con gradissima spesa e vergogna e danno de'Fiorentini, é quasi incredibile che Castruccio tenesse l'assedio a Pistoia con $160($ ) cavalieri. E li Fiorentini n'avcano più di $3 \mathrm{~m}$ con grandissimo popolo, e non potcro levarlo da canpo" (Agnolo di Tura, in Muratori, Rerum italicarum scriptores, cronache senesi, 476).

68 Giovanni Villani, Cronaca, x, 104.

69 W. M. Bowsky, The Finance of the Commune of Siena 1287 1355 (Oxford, 1970), 45.

70 Giovanni Villani, Cronaca, x, 57 .

71 Giovanni Villani, Cronaca, x, 102.

72 Agnolo di Tura, in Muratori, Rerum italicarum scriptores, cronarhe senesi, 503 and 505 . 
THE EARIYY TRIUMPHAL DECORATION IN THE PALAZZO PUBBLICO OF SIENA

The Guidoriccio fresco belonged to a series of images of conquered or otherwise acquired forts or towns which decorated the Palazzo Pubblico of Siena. ${ }^{73}$ Of these only two remain: the Guidoriccio and the new fresco below. This triumphal iconography, together with the cult of the Virgin protectress of Siena as represented by Simone Martini's Maestà, constituted the principal themes of the early pictorial decoration of the Sala del Consiglio in the Palazzo Pubblico during the early years of the trecento following its completion. The recently uncovered fresco of the mountain hamlet surrendering to Siena beneath Guidoriccio is the earliest extant example of this triumphal iconography that has survived. As has been indicated, whether it represented the surrender of Giuncarico is uncertain. However, according to the sources, when Giuncarico was painted there in 1314 more than one such conquered (or otherwise acquired) site was already present in the same hall. ${ }^{74}$ From the humble appearance of this mountain hamlet on the new fresco, and also from the other depicted sites named in the documents, it is evident that the Sienese were hardly selective regarding the relative significance of these newly acquired places. Rather, these paintings served as a cumulative visual record of Siena's ongoing territorial expansion. However, as the memory of the lesser conquests or submissions dimmed with passing years, the scenes representing them in the Sala del Consiglio, or wherever else in the Palazzo Pubblico they might have been located, lost their original significance. Accordingly, some thirty years after its creation, the new fresco with its humble mountain hamlet had already disappeared beneath Ambrogio Lorenzetti's Mappamondo. The fact that of this early triumphal decoration only the Guidoriccio fresco was allowed to survive further substantiates this view. Indeed, by the 1340 s a remarkable transformation in the intellectual vision and refinement of Siena's propaganda of state had

73 Concerning the early triumphal decoration of the Palazzo Pubblico, see Seidel, "'Castrum pingatur in palatio,' " passim: Polzer, "Simone Martini's Guidoriccio da Fogliano," 105ff.; also, recently, Borghini, in Palazzo Pubblico di Siena, $215 \mathrm{fr}$

74 On 30 March 1314, the Consiglio della Campana provided for the painting of the castle of Giuncarico "in palatio communis sen|ensis]' ubi fiunt consilia, ubi sunt picta alia castra acquistata per comune sen[ensis]" (A.S.S., Consiglio Generale, 83, 120r.). Giuncarico was hardly a site of major importance. This leads to the question of which other castles or towns might have been depicted earlier in the Palazzo P'ubblico. For what this may be worth, Grosseto surrendered to Siena in 1310, and Sinalunga in 1312 . These would surely have been more deserving of pictorial representation within this triumphal series occurred. While the earlier triumphal records were tied to the historical moment, now, with Ambrogio's Mappamondo (where Siena appeared at the centre of the "oikoumene"75) and his Pace $e$ Guerra frescoes in the adjacent Sala dei Nove, the state of Siena was represented as rising above the historical moment in perpetuity in a grand geographical and allegorical design. ${ }^{76}$ Of this earlier triumphal decoration the Sienese no doubt allowed the Guidoriccio fresco, exceptionally, to survive in its prime location opposite the Maestàand here the respect for Simone Martini's authorship could well have been a contributing factorbecause Guidoriccio's victory marked the defeat of perhaps the greatest general the Renaissance produced. It is interesting that the two other triumphal frescoes still present in the same hall, both of a later date, document not territorial expansion but the defeat of a respected enemy: Lippo Vanni's fresco of 1363 recording the defeat in the previous year of the English company of the cappello in the Val di Chiana, and the victory of 1479 near Poggibonsi over the Florentines painted by Giovanni di Cristofano and Francesco d'Andrea.

Closer examination of this early triumphal decoration in the Palazzo Pubblico documents how closely these frescoes were tied to the events depicted. Indeed, their creation included certain legal, even ceremonial, components. In the case of Giuncarico, which submitted voluntarily to Siena in 1314, the transfer of power document specified that Giuncarico was to be depicted in the Palazzo Pubblico and that it was forbidden to remove or damage this picture. ${ }^{77}$ Even if the picture was destined to be eventually obliterated, at the time of Giuncarico's acquisition it was intended to remain

C. Frugoni, "Il governo dei nove a Siena e il loro credo politico nell'affresco di Ambrogio Lorenzetti," Quaderni Medievali (June 1979), 14-42, and (December 1979), 71 103; E. Carter-Southard, "Ambrogio Lorenzetti's Frescoes in the Sala della Pace: A Change of Names," Mitteilungen des Kunsthistorischen Institutes in Florenz, xxı (1980), $361-65$.

75 (oncerning Ambrogio Lorenzetti's Mappamondo sec Carter-Southard, "The Frescoes in Siena's Palazzo Pubblico," and Borghini, in Palazzo Pubblico di Siena: also, with reference to Sicna being represented at its centre, sec Enzo Carli, in Bernardino predicatore nella società del suo tempo. Ott. 9-12, 1975, Todi, Convegni del centro di studi sulla spiritualità medievale. XVI (Todi, 1976), 172f.

76 Concerning the political iconography of Ambrogio Lorenzcti's Pace e Guerra see N. Rubinstein, "Political Ideas in Sienese Art: The Frescoes of Ambrogio Lorenzetti and Taddco di Bartolo in the Palazzo Pubblico," Journal of the Warburg and Courtauld Institutes, xxı (1958), 179-207: H. Feldges-Henning, "The Pictorial Programme of the Sala della Pace: A New Interpretation," Journal of the Warburg and Courtauld Institutes, xxxv (1972), 145-62;

77 "F. nunquam possit talis pictura tolli, abradi ut vituperari" (A.S.S., Consiglio Generale 83, $119 \mathrm{ff}$.). The document is given by Seidel, “'Castrum pingatur in palatio," " 36 . 
graven forever in the commune's vision. Obviously the painting's efficacy depended on topographical "truth" as this would have been understood at the time. In at least one case the depiction of conquered sites was planned prior to the declaration of peace. On 12 August 1331, Guidoriccio captured Arcidosso from the counts of Santa Fiore. ${ }^{78}$ Peace was not agreed upon until 18 November. It legalized Siena's conquest of Arcidosso and Castel del Piano and Siena paid a substantial fee to the counts of Santa Fiore, who relinquished all claims to these towns. ${ }^{79}$ Yet considerably before the declaration of peace, on 6 September, Simone Martini was sent by the commune to draw these towns in situ. ${ }^{80} \mathrm{He}$ was paid on 14 December for having painted them in the Palazzo Pubblico. ${ }^{81}$ This sequence of events informs us that the Sienese government intended to have these conquered towns depicted even before the cessation of hostilities. There could have been but one purpose intended: that these frescoes should have been ready for display at the celebration of the triumph.

\section{CONCERNING THE ORIGIN OF THE GUIDORICCIO FRESCO}

Surely the same was true of the Guidoriccio fresco. Let us consider the events surrounding the victory at Montemassi. Towards the end of the siege Castruccio sent a force of six hundred cavalry to Montemassi, which arrived on 25 August. This time the tables were turned: the Sienese and their Florentine allies were too strong and Castruccio's force retreated. The defenders gave up hope and surrendered a patti on 27 August. The next day the Sienese entered the fort. The Sienese army then moved on into Pisan territory. Only on 10 September did Guidoriccio and his troops enter Siena "with great celebration and happiness; there were in Siena bonfire and grand triumphs." ${ }^{82}$ Accordingly, nearly two weeks elapsed between the capitulation of Montemassi and the army's triumphal return to Siena. This would have been sufficient time for the fresco to have been painted.

78 Agnolo di Tura, in Muratori, Rerum italicarum scriptores, cronache senesi, 503.

79 A.S.S., Caleffo dell'Assunta, Capitoli n. 2, 334-339v. The document is quoted by Seidel. "Castrum pingatur in palatio," appendix $6,38 \mathrm{ff}$.

80 A.S.S. Biccherna 397, 123v. The document is quoted by Scidel, "'Castrum pingatur in palatio,"” 34 n. 97.

81 "Anco al maestro Simone dipegnitore e quagli ebe per suo salaro e qualle tolse a rischio a dipegnare nel palagio del Chomune Arcidoso e Chastello del Piano in sette fiorini d'oro, avene puliça da Nove... Lib. 22 s. 8" (A.S.S., Biccherna $171,81 \mathrm{v}$.). The document is quoted by Seidel, “'Castrum pingatur in palatio," 25.

82 Agnolo di Tura, in Muratori, Rerum italicarum scriptores, cronache senesi, $477 \mathrm{f}$
One may propose the following sequence of events: By 28 August news of Montemassi's fall would have reached Siena since negotiations for its surrender had been concluded the day before. ${ }^{83}$ Quickly, the nove decided on the fresco's creation and location. Simone agreed to paint it. At the time he and his close associates received the principal Sienese commissions: he was then virtually the official painter of the commune. ${ }^{84}$ Quickly erecting the needed scaffold presented no problem. In the meantime Simone Martini worked on the basic composition, searching for a concise effective scheme which could be realized within the short time available. He decided on using just one figure: the equestrian general set before the landscape. He then added the fort, the Sienese encampment, the so-called battifolle. With some of these features he was already familiar. The tents he repeated essentially after those he had painted at Assisi. ${ }^{85}$ The general landscape extending from Montemassi northward to Poggio Colombo could have been drawn or explained to him by a knowledgeable party who had been at the siege. In the meantime he could have sent someone immediately for a more detailed sketch of Montemassi. Since he painted the fresco from right to left, as he had done at Assisi and on the Maestà in the same hall, ${ }^{86}$ the fort belonged to the last (or close to last) giornata. Starting at the upper right side, he did not even bother to prepare new plaster, but drew initially on the old one already in place. Of course, this did not matter since the azurite of the sky was applied dry and would cover it. However, after this hurried beginning he then applied fresh plaster for each giornata, as was customary. The fortress in back of Guidoriccio is not the actual battifolle erected at the siege; it is an imaginary structure. With the two banners rising from it displaying the balzana as well as his own coat-of-arms, it undoubtedly symbolizes Siena's defensive military power. ${ }^{87}$ A contributing factor regarding his composition of this symbolic fortress may have been his lack of knowledge of what it looked like at the time he had to paint it. Or he may

83 Agnolo di Tura, in Muratori, Rerum italicarum scriptores, cronache senesi, 477.

84 See the paper presented by Fdna Carter-Southard at the Simone Martini congress held at Siena in March 1984, to be published in the acts.

85 Sec the tents of the Huns in the scene of Saint Martin Renouncing the Use of Arms, reproduced in (;. Contini and M. C. Gozzoli, L'opera completa di Simone Martini (Milan. 1970), pl. xxiv-I).

86 See Tintori, technical report available at the library of the Kunsthistorisches Institut in Florence, 11-16.

87 Onc element which links this fort to a battifolle is the catapult within. 'This catapult is quite abbreviated. A more complex one appears on an ivory mirror box of the fourteenth century in the Bargello (cat. no. 128c). 
have found the actual battifolle insufficiently attractive for inclusion in so significant a painting. Possibly by the time he got to the Montemassi section of the fresco, a drawing of the fort would already have been available, since it belonged to the last portion to be completed. The large giornate, the stesura frettolosa underscored by Gavazzi (which he considered incompatible with trecento fresco painting), would have resulted directly from the urgency involved in the fresco's creation. By the time Guidoriccio and his army returned to Siena, the fresco would have been there to greet them in triumph, plausibly with certain detailed ornamental features remaining to be completed. I should not be surprised if Guidoriccio's foray into Pisan territory after the fall of Montemassi was intended to give Siena sufficient time to prepare a grand triumphal reception for its victorious army.

There is one apparent hurdle to this thesis, the record of payment dated 2 May 1330: "Also [again] to master Simone painter the sixteen lire which we owe him for the painting he made of Montemassi and Sassoforte in the palace of the commune so we are instructed by the Nine Lords." 88 This record of payment was made about a year and eight months after the fall of Montemassi. It also dates a month and a half after the purchase of Sassoforte by Siena from the counts of Santa Fiore which took place on 18 February 1330. In a related context Simone was paid on 14 December 1331 for painting Castel del Piano and Arcidosso in the Palazzo Pubblico, not too long after the official declaration of peace on 18 November with the counts of Santa Fiore, their former lords from whom these towns had been taken. ${ }^{89}$ Here too payment followed reasonably closely after the actual painting. How then can the considerable lapse in time separating the date of payment from the victory at Montemassi be explained? At the moment, no precise answer can be

88 "Anco al maestro Simone dipentorc le quali sedici lire li demmo per la dipentura che fece di Monte Massi c Sassoforte ncl palaççio del Comunc et avemmone poliça da Signori Nove" (A.S.S., Biccherna 165, 3lv.). In the reading I follow Scidel, "'Castrum pingatur in palatio,," 25. See also U. Feldges-Henning, "Zum Ihema und 1)atierung von Simone Martinis I'resko 'Guido Riccio da Fogliano,'" Mitteilungen des Kunsthistorischen Institutes in Florenz, XVII (1973), 274. See also Agnolo di Tura, in Muratori, Rerum italicarum scriptores, cronache senesi, 496: "Montemassi e Sassoforte li fero dipcgnare i signori Nove di Siena, a l'esenplo come erano, i quali furo dipenti nel palazo grande di sopra nclla sala, e fù il maestro Simone di Lorenzo [sic] da Siena ottimo macstro, fù d'aprile 1331." Concerning the limited reliability of this chronicle which would account for the confusion concerning Simone Martini's name, see A. I.isini, xxff.; in Agnolo di Tura, in Muratori, Rerum italicarum scriptores, cronache senesi.

89 The document is quoted by Seidel, " 'Castrum pingatur in palatio,'" 38 appendix 6 . given. The document of payment begins with "anco," meaning "again, still," so we may be dealing with a partial payment. ${ }^{90}$ It is possible that the drastic financial situation of the commune during these years, brought about by heavy military expenditures as well as extreme famine ${ }^{91}$ might have led the commune to arrange with Simone for partial later payment, although the drastic cost of dealing with these crises hardly compared with that of one fresco. The total payment for the Guidoriccio fresco and its disbursement remain open questions. ${ }^{92}$

\section{SOME GENERAL CONSIDERATIONS CONCERNING MEDIEVAI. HISTORY REPRESENTATION IN ART}

The Guidoriccio polemic has brought about a closer consideration of the role of triumphal and related political history representations in the protoRenaissance Tuscan communes. We have become aware of their presence in Florence and in other Italian cities ${ }^{93}$ It should be remembered, however,

90 See also Carter-Southard, "The Fiescoes in Sicna's Palazzo Pubblico," 229.

9l For a discussion of the communal costs applied towards faminc rclief see, generally, W. M. Bowskw, The Finance of the Commune of Siena 1287-1355 (Oxford, 1970), 33. ff., and concerning the cost of the siege of Montemassi, amounting to close to 100,000 gold florins but slightly less than the entire ordinary budget of the Biccherna during 1328 , see Bowsky, The Finance of the Commune of Siena, 15, with reference to A.S.S., Consiglio Generale 106, 41r.-48r., esp. $46 r$.

92 It is interesting to note that according to the extant evidence, lor painting Arcidosso and Castel del Piano Simone Martini received seven gold llorins, which exceeds considerably the five gold florins he received on 2 May 1330, for painting Montemassi and Sassofortc. Since of these paintings only the Guidoriccio fresco has survived, to make any tangible comparison regarding scale and condition of painting with payment received is impossible.

93 For example, the batule of Campaldino of 1289 was depicted in the Bargello (see R. Davidsohn, Geschichte von Florenz [Berlin, 1886], 11-1, 351). See also Seidel, "'Castrum pingatur in palatio," " 33; also H. Wicruszowski's interesting study, "Art and the Commune in the Time of Dante," Speculum (1944), 14-33. She discusses the broad range of visual rhctoric, reaching from direct narrative to complex allegory, cvident in history painting in the service of the Tuscan proto-Renaissance communc. See also the deliberations of the Priori delle Arti and the Gonfaloniere di Giustizia of Florenze of 20 June 1329 concerning what subject matter is acceptable for decorating public cdifices (A.S.F., Provvisioni Registri 25, 42v.-43r., quoted by Seidel, "'Castrum pingatur in palatio," 41 appendix 7). Significantly, a number of pictorial representations of historic events dating from the thirteenth century have survived, or are referred to in the documents, in the north Italian communes. 'The Cremonese recorded in painting their victory of 1213 over Milan and its allies (G. Zaist, Notizie istoriche de'pittori, scultori ed architetti Cremonesi [Cremona, 1774], 12). The defeat and imprisonment of Napoleone della Torre by Ottone Visconti, bishop of $\mathrm{Mi}$ lan, which took place in 1277, is still to be seen in the main 
that this constitutes but one small sample of a category of medieval artistic production of which very little has survived from earlier times. Surely, the visual recording of historical events was known throughout the Middle Ages. The purpose and character of historical narrative art certainly varied in accordance with the kind of master it served, whether emperor, king, nobleman, or free commune. The documents yield but a small fragment of what must have once represented a large body of medieval artistic production. Lack of evidence notwithstanding, it seems difficult not to assume that Charlemagne decorated his palaces with scenes of his victories, the crusaders the walls of their castles with the taking of Jerusalem, or Philippe Auguste his palace with the battle of Bouvines, just as, mutatis mutandis, the Roman emperors had chronicled their victories in stone relief or Baron Gros was to enshrine Napoleon's victories on canvas. Some medieval triumphal art is documented, from both Byzantium ${ }^{94}$ and the West. The victories of Charles Martel, Pepin, and Charlemagne once decorated the council chamber of Louis the Pious's palace at Ingelheim, together with a grand series of epic deeds reverting to classical times. ${ }^{95}$ Henry I decorated the dining hall of his palace at Merseburg with his victory of 933 over the Hungarians. ${ }^{96}$ The Bayeux embroidery, the unique surviving early medieval example of historical triumphal art used as monumental decoration, was surely a familiar type of art object when it was created. ${ }^{97}$ Within this triumphal series

hall of the Rocca Borromeo in Angera. Pictro Toesca dates these frescoes after 1314 (La pittura e la minialura nella Lombardia ['[urin, 1966], 83ff.). However, recently they have been placed carlier, in the dugento (C. Segre: Montel, in many authors, La pittura in Italia. Il duecento e il trecento, I /Venice. 1986], 46; also C. Pirovani, in La pittura in Italia, 1, $86 \mathrm{n}$. 1). See also the fragmentary representation of the peace of 1298 between Guelphs and Crlibellines brought about by Bernardo Maggi, bishop and lord of Brescia, in the Broletto (S. Matalon. Affreschi lombardi del trecento [Milan, 1963], 357f. pls. 17-24). John Larner (in Italy in the Age of Dante and Petrarch, 1216-1380 |I.ondon and New York, 1980], 132) refers to the brutal exccution in 1259 by the victorious Venetians of Alberico da Romano and his family which was depicted at the time in 'reviso's Palazzo del Consiglio.

94 The victories of Belisarius in Italy and Africa were represented in mosaic in the chalce of the imperial palace in Constantinople (Procop., De aedif., I, 10, 204); the military feats of Basil I decorated the main hall of the Kenourgion Palace (Const. Porphyr., Vita Baszl. Maced.: Migne, P.G., 109, 348); The Comnenc emperors Manuel I and Andronicus I decorated their palaces with scencs of military feats as well (see A. (Grabar, L'empereur dans l'arl byzantin [Paris, 1936], 82f.).

95 Ermoldi Nigelli, De rebus gestis Ludovici Pii: Mignc, P.L., 105,6241 .

96 Liutprandus Cremonensis episcopus, Antapodosis, II, 31: Migne, P.L., 136, 823.

97 Sce the poem of Baudry de Bourgueil which describes a also belonged the crusader window in the abbey church of Saint Denis, documenting a grand religious ideal which had unified a politically dismembered West into collective military action. ${ }^{98}$ An interesting wooden sculpture once located in the Cathedral of Notre Dame in Paris, iconographically related to the equestrian Guidoriccio of the Sienese fresco, represented the equestrian Philippe le Bel in armour. It commemorated his victory over the Flemish communes at Mons-enPevèle in $1304 .{ }^{99}$ The low survival rate of medieval history art was tied to its limited scope-the propagandistic interest of individuals or dynasties which came and went-as compared to that of religious art with its cternal message. There is also the adjunct factor of medieval art employing less permanent artistic media than stone, which has preserved so much of history art from ancient times. Of course, in art dealing with historic narrative, triumphal subject matter prevailed. Although in dynastic propagandistic contexts epic triumphs culled from earlier periods were included in some of these propagandistic schemes, the emphasis lay on the contemporary scene: the triumphs, the gesta of the actual ruler. And the contemporary triumph would tend to have been represented, within the accepted artistic norms, in a recognizable topographical manner. ${ }^{100}$

Topographical "truth" and contemporaneity are the two basic "rules" of history art serving the proto-Renaissance Tuscan commune. Within the collective structure of the commune with all its political vicissitudes this kind of art included, besides the recording of triumphs against external foes, the visual proclamation of treason, traitors, and criminals, of political opponents punished: the so-called pittura infamante. It perpetuated the town crier's voice in visual form. ${ }^{101}$ It is hardly

wall hanging in the bed chamber of the Countess Adele de Blois, daughter of William the Conqueror, which also depicted the Norman invasion of England (see (). K. Werckıneister, in Sudi medievali, scr. 3, xvil, 2 [1976], 557 (r.).

98 See, recently, E. A. R. Brown and M. W. Cothren, "The Twelfth-Century Crusader Window in the Abbey of Saint-Denis," Journal of the Warburg and the Courtauld Institutes, Xux (1986), 1-11, with a proposed dating into the abbacy of Suger or, more probably, that of his successor Odo of Deuil, around 1158

99 F. Baron, "I ce cavalier royal de Notre-Dame de Paris et le problème de la statuc équestre au Moyen- $\Lambda$ ge," Bulletin Monumental, cxxvi (1976), 141-254; also Pol\%cr, "Simone Martini's (iuidoriccio da Fogliano," 132.

100 See the discussion of the reduced architectural representations in the Bayeux cmbroidery by R. Allen Brown. in F. S. Stenton and others, The Baypux Tapestry (London. $1965), 7611$

101 Among relevant examples sce Giottino's paintings of the Duke of Athens and his followers represented, after his banishment from Iilorence in 1343, as examples of mis- 
surprising that the comparatively large number of early examples of history art we know of derive from those communes that continued to cherish their early history, especially Siena. Triumphal art, exemplifying their virtus, also decorates certain tombs of despots. ${ }^{102}$

These principles of topographical "truth" and contemporaneity applied as well to the early series of acquired towns, which decorated the Palazzo Pubblico in Siena; certainly Simone Martini's paintings of Arcidosso and Castel del Piano, and Sassoforte and Giuncarico as well. Nor would the Guidoriccio fresco have differed. Witness the date of the siege, 1328, written at the centre of the lower border. ${ }^{103}$ Witness also the painted fort, which reproduces (in repainted form) two structures that are still extant at Montemassi (Figs. 13-14).

\section{THE PAINIED LANDSCAPE AND THE SIEGE OF MONTEMASSI (FIG. 32)}

Let us review in what measure the painted landscape with its architecture would refer to the actual siege. To a degree, the topography and the architecture are correct. The two highest structures of the painted fort still exist (Figs. 10-11). They belong to a repainted portion of the fresco and seem to relate to the original painted fort, although this

government on the tower of the Bargello (Vasari, ed. Milanesi [1878-], 1, 626). The pittura infamante appears in Florence throughout the Renaissance, involving outstanding painters: witness Andrea del Castagno's painting of the hanged cnemies of the Medici which earncd him the nickname of Andrea degli impiccati (M. Salmi, Andrea del Castagno [Novara, 1961], 56). Witness also Botticelli's recorded paintings of the hanged conspirators of the Pazzi rebellion (H. P. Horne, Botticelli Painter of Florence |Princeton, N.J., 1980 reprint], $62 \mathrm{f}$.). The element of chronological proximity implicit in the pittura infamante is documented in the directive of 31 December 1390 , given by the commune ol Sicna to Bartolo di Fredi instructing him to interrupt his work at Monte Oliveto in order to paint rebels in the Sala del Consiglio of the Palazzo Pubblico of Siena (A.S.S., Consiglio Generale 158, f. 13-referred to by Ugo Morandi, in Palazzo Pubblico di Siena, 42.3 document 29). For another interesting example see the recording in painting by Bettino in 1312-13, in the Cathedral of Prato, of the attempted theft and execution of Giovanni di Ser Landetto. He was caught robbing the sacra cintola from the cathedral in order to bring the relic to Florence (I)avidsohn, Geschichte von Florenz, IV-3, 222) For a fuller discussion of the pittura infamante, see G. Ortelli, "Pingatur in Palatio ...": La pittura infamante nei scioli xizi-xvi (Rome, 1979)

102 The two proto-Renaissance tombs so decorated, that of Guido Tarlati in the Cathedral of Arezzo and the one of Can Grancle della Scala in S. Maria Antica in Verona, both date close to the Guidoriccio fresco (reproduced in Polzer, "Simone Martini's Guidoriccio da Fogliano," 135 figs. 24 and 25). Concerning the Tarlati tomb see Annarosa Garzelli, Sculture toscane nel dugento e nel trecento (Pisa, 1968), $87 \mathrm{ff}$.

103 For Martindale's later dating of the Guidoriccio fresco see the Appendix. relationship cannot be proved. A detailed architectural profile of the fort, which might assist in the dating of its component parts, is not available. It already existed in the eleventh century. A cursory examination of the ruins indicates that they represent many building phases and repairs, extending over centuries. Certain structures, such as the southern tower, ${ }^{104}$ date back to medieval times (Fig. 30). What complicates the unravelling of the history of military fortifications such as this one is that they were continually repaired and added to as they were damaged in war. The painted landscape considered in its entirety undoubtedly conforms to a view from the east, as Uta Feldges has proposed. ${ }^{105}$ Indeed, the respective outlines of the actual and painted landscapes correspond (Figs. 12 and 14). Italo Moretti concurs, identifying the high hill at the right side of the fresco as Poggio Colombo, the highest point near Montemassi, rising about one kilometre to the north. ${ }^{106}$ It must be noted that the overall view of the painted landscape from the east does not correspond to that of the two structures reproduced on the painted fort which, assuming their reliability, are seen from the northwest (Fig. 13). This inconsistency concerning the directional relation of the whole to a part hardly compromises the intended veracity of the image according to the artistic conventions prevailing at the time; as has been considered, they did not yet require the application of a coordinate optical vantage point.

Agnolo di Tura writes that Guidoriccio thought the fort impervious to assault, and therefore prepared for a siege. ${ }^{107}$ Obviously, he would have used the terrain to maximum advantage. The fort is set on a high rock. To the south this rock slopes sharply into the rich plain of the Maremma (Fig. 30 ). To the east and west are lower ground and foothills. To the north a high ridge curves in a crescent towards Poggio Colombo and the mountains beyond, and this ridge comprises elevations near the fort, which would have been suitable for locating a temporary siege structure. Certainly, Guidoriccio secured his army on the highest available ground along this ridge and Poggio Colombo. From the top of the latter he could screen the surrounding

104 Witness, for example, the sculpted corbel in the southern tower (Fig. 31). I am grateful to Michael Braune for sharing his knowledge of medieval fortifications with me. Concerning the history of the fort of Montemassi, see especially E. Repetti, Dizionario geografico, fisico e storico della Toscana (Florence, 1839), III, 430ff., and many authors, I castelli del Senese (Siena, 1985), 225, 259, 362f., cat. no. 48-8.

105 Feldges, Landschaft als topographisches Porträt, $142 \mathrm{f}$

106 Italo Moretti, in Prospettiva, xxiII (October 1980), 66ff.

107 Agnolo di Tura, in Muratori, Rerum italicarum scriptores, cronache senesi, 464 . 


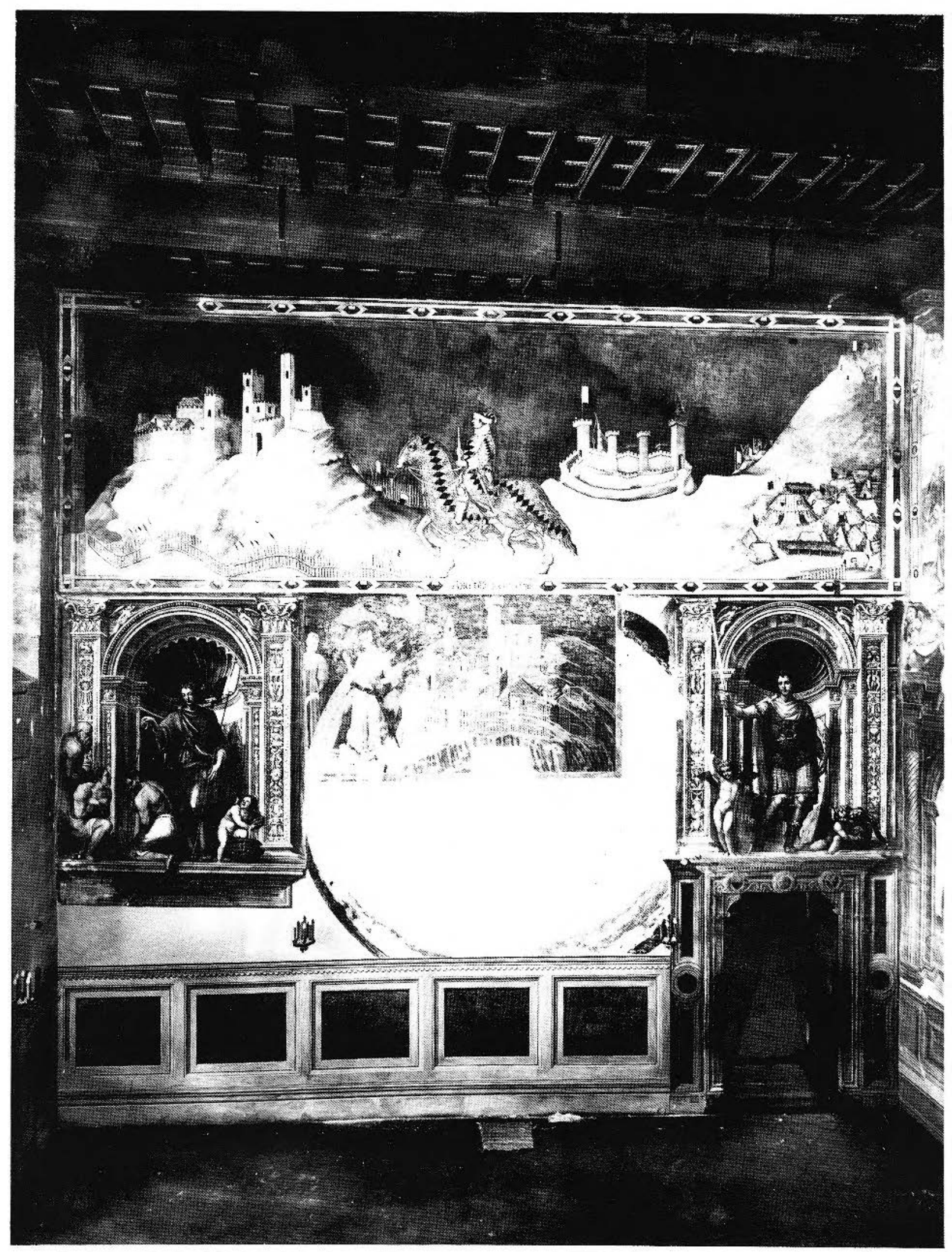

Figlike 4. Sala del Mappamondo, wall with the Guidoriccio fresco. Siena, Palazzo Pubblico (Photo: Kunsthistorisches Institut Florence). 


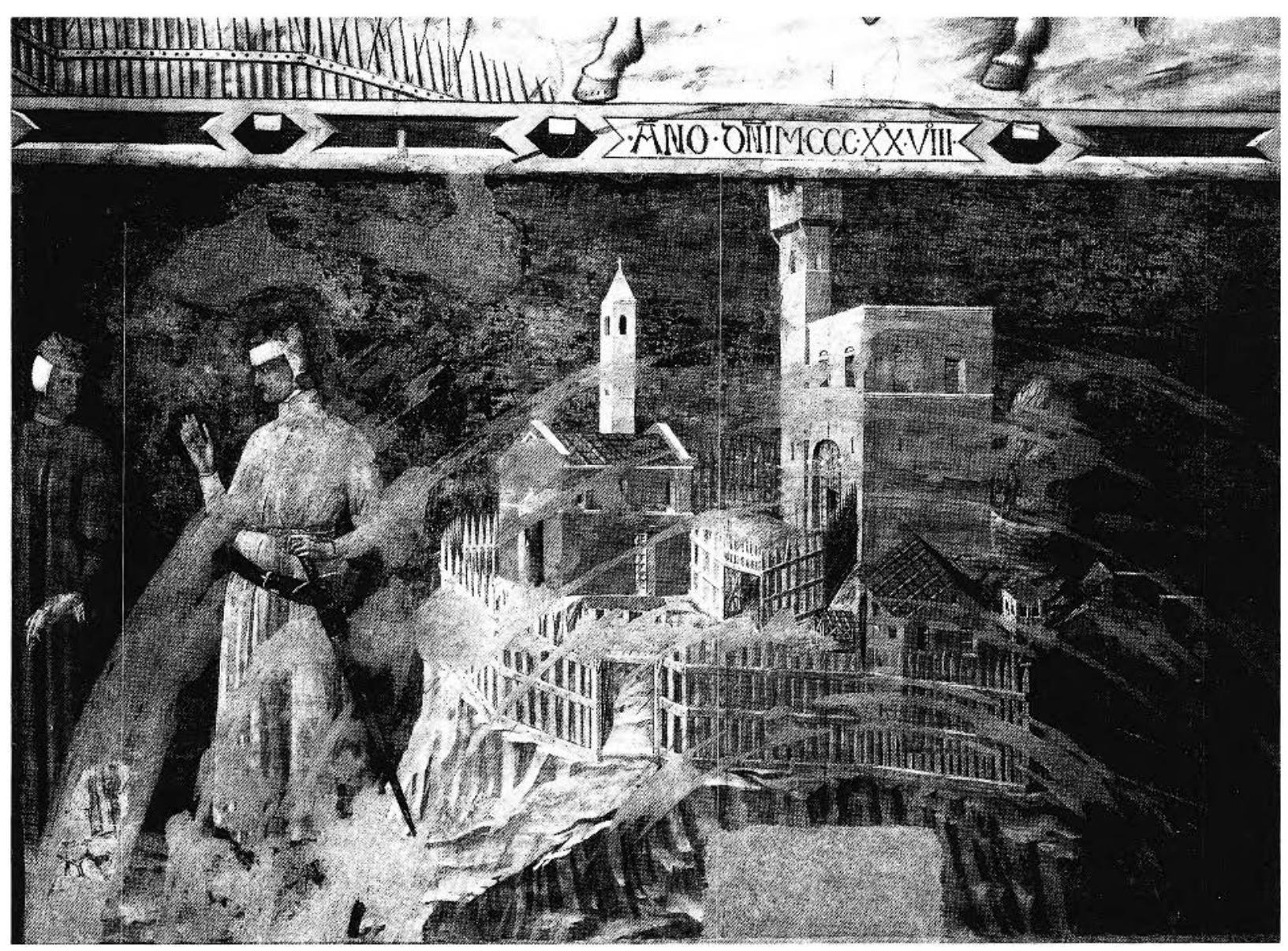

Figurf. 5. Sala del Mappamondo, the recently discovered fresco, A Mountain Hamlel Surrenders to Siena. Siena Palazzo Pubblico (Photo: Kunsthistorisches Institut Florence). 


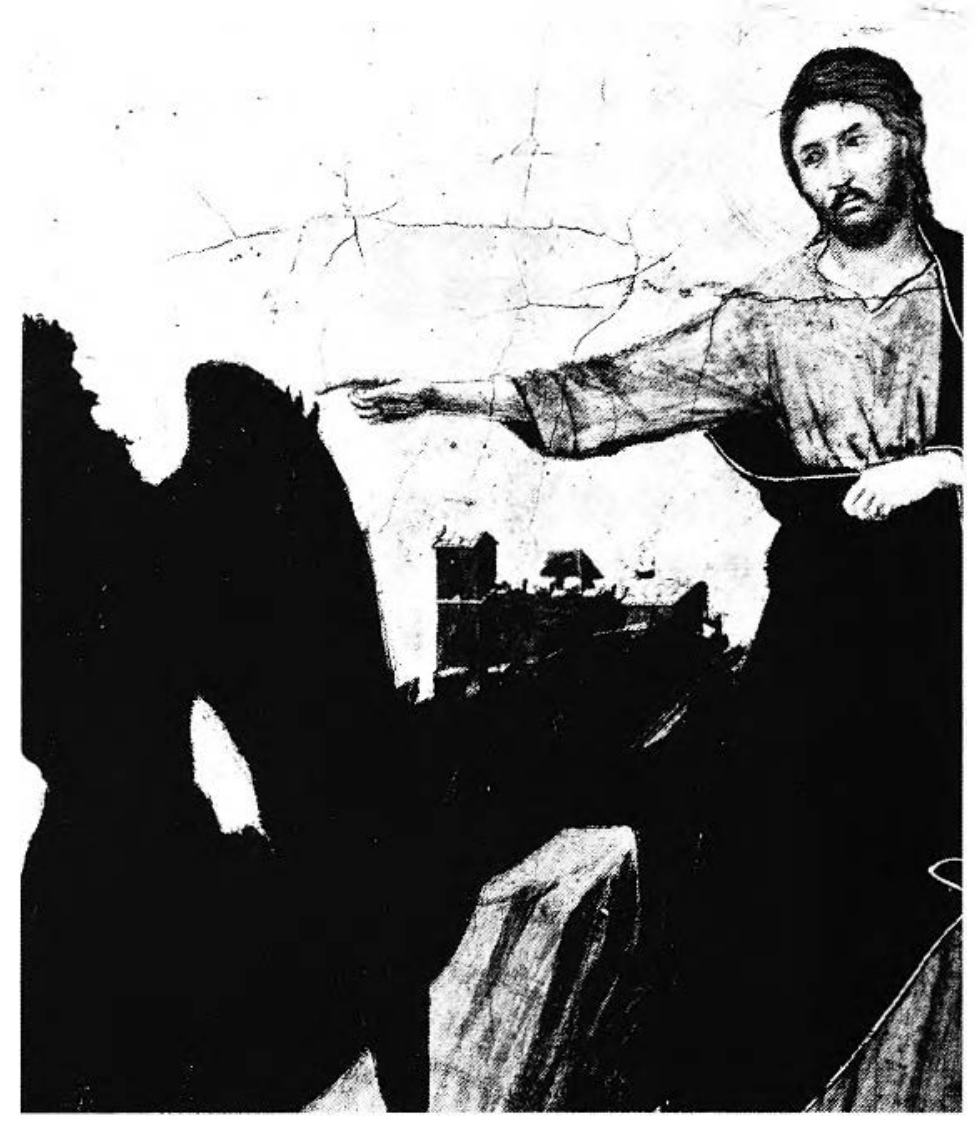

ligurr: 6. Duccio, Maestì, Christ Tempted on the Mountain, Frick Collection, New York City (Photo: Frick Collection, New York (iity)

Figtirf. 7. Duccio, Maestà, Incredulity of Thomas, Siena, Museo dell'Opera del Duomo (Photo: Soprintendenza B.A.S., Siena).

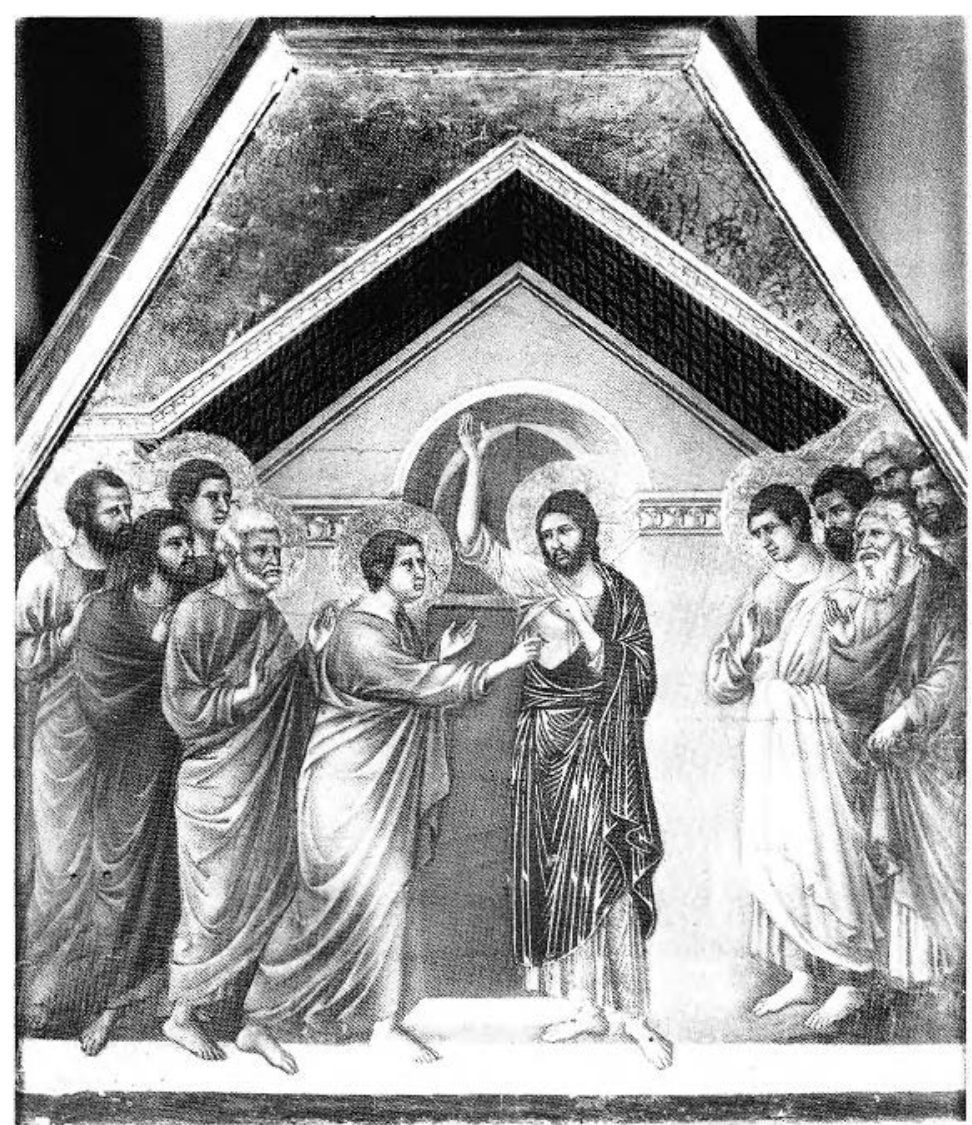


Fis:ure 8. Memmo di Filippuccio, detail of fresco, San Gimignano, Palazzo ('ommunale (Photo: Soprintenden`a B.A.S., Sicna).
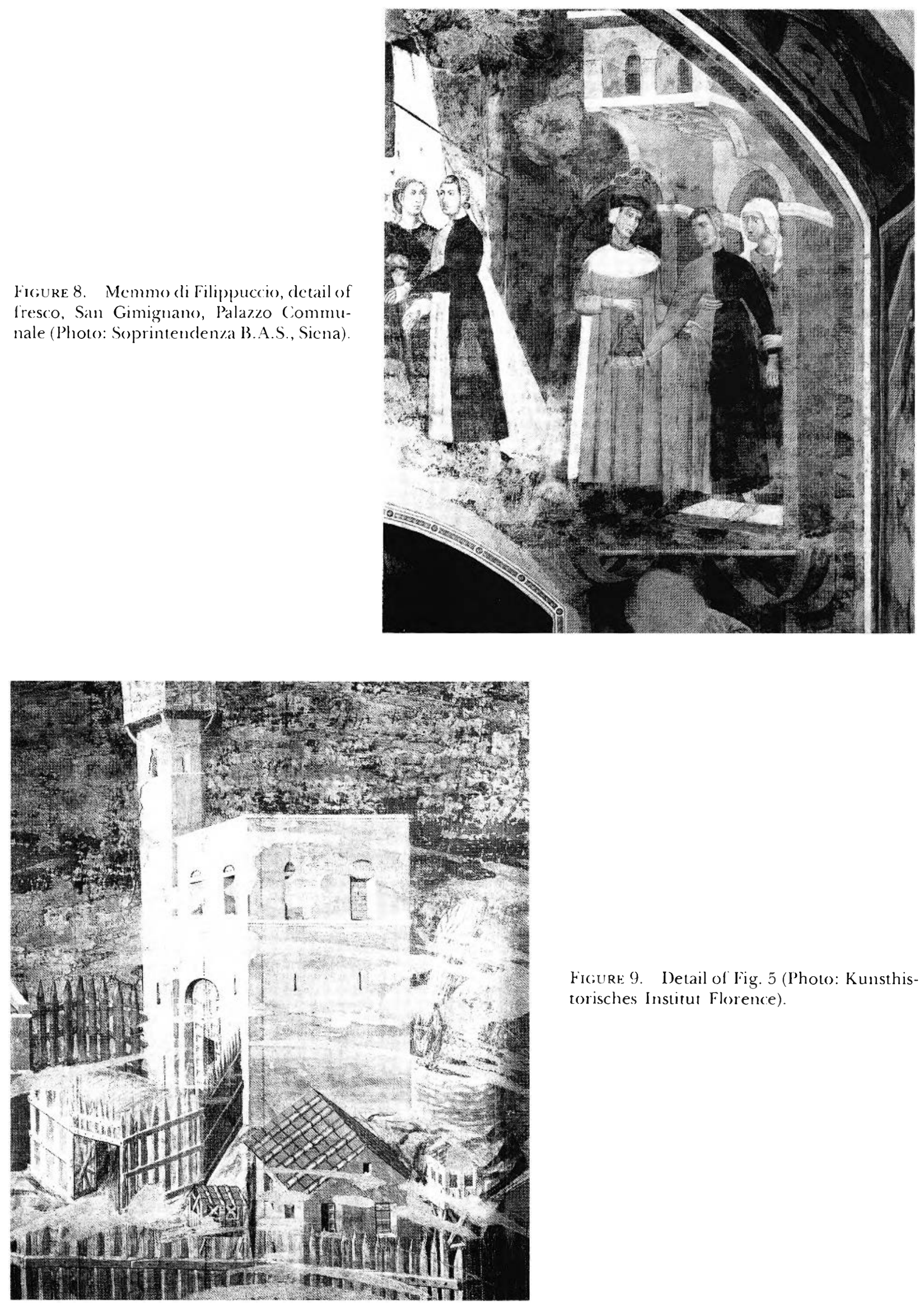

Figure 9. Detail of Fig. 5 (Photo: Kunsthistorisches Institut Florence). 


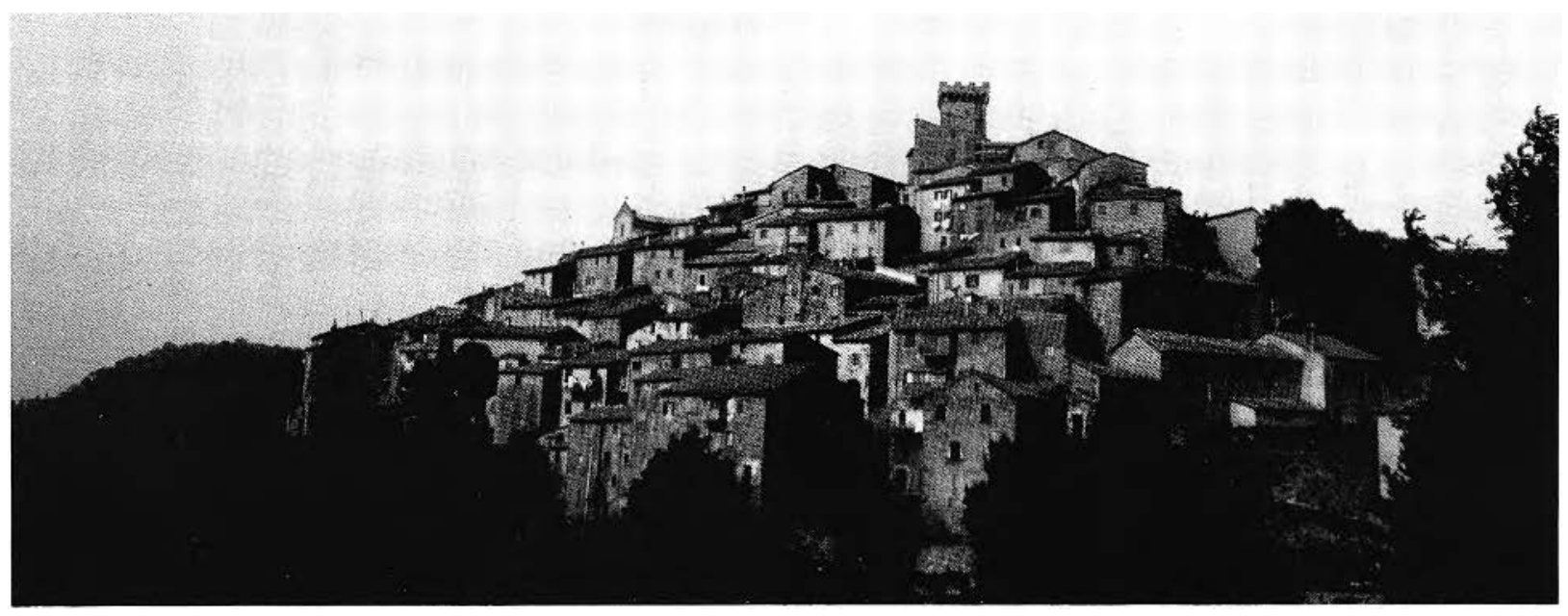

Figure 10. Arcidosso, view of town (Photo: Author).

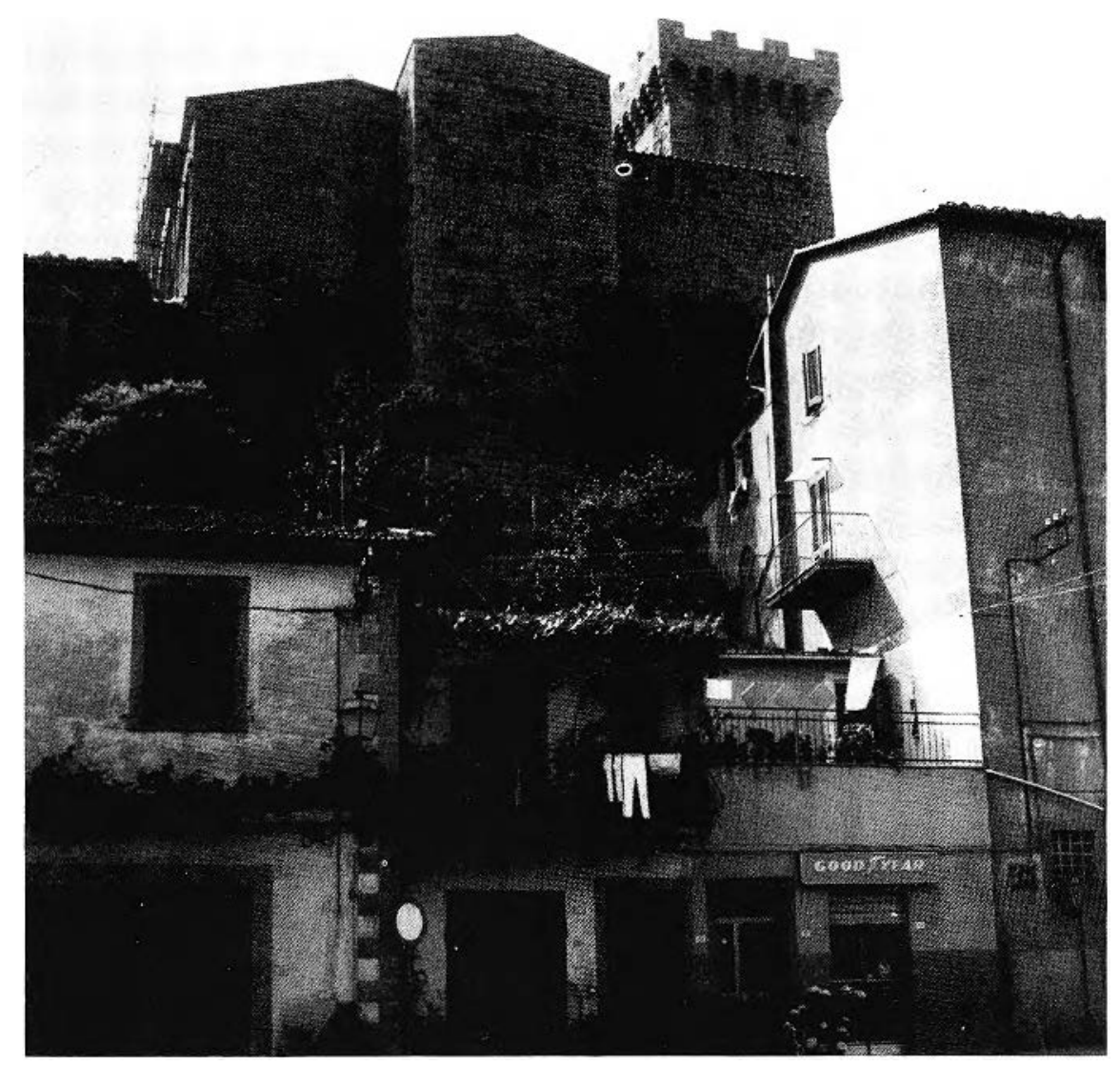

Fisurf. 11. Arcidosso, Castello (Photo: Author). 


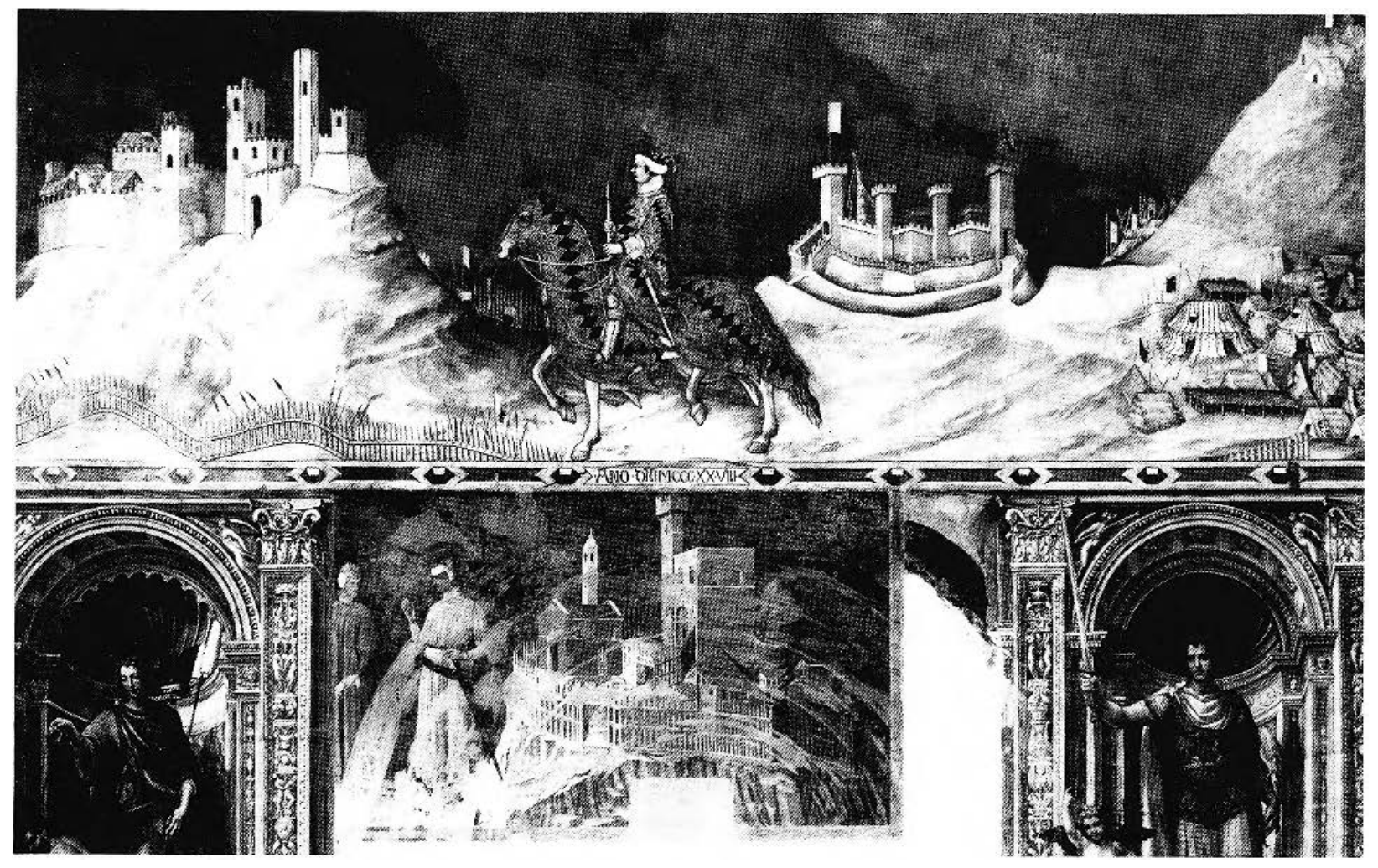

Figure 12. Detail of lïg. 4. 


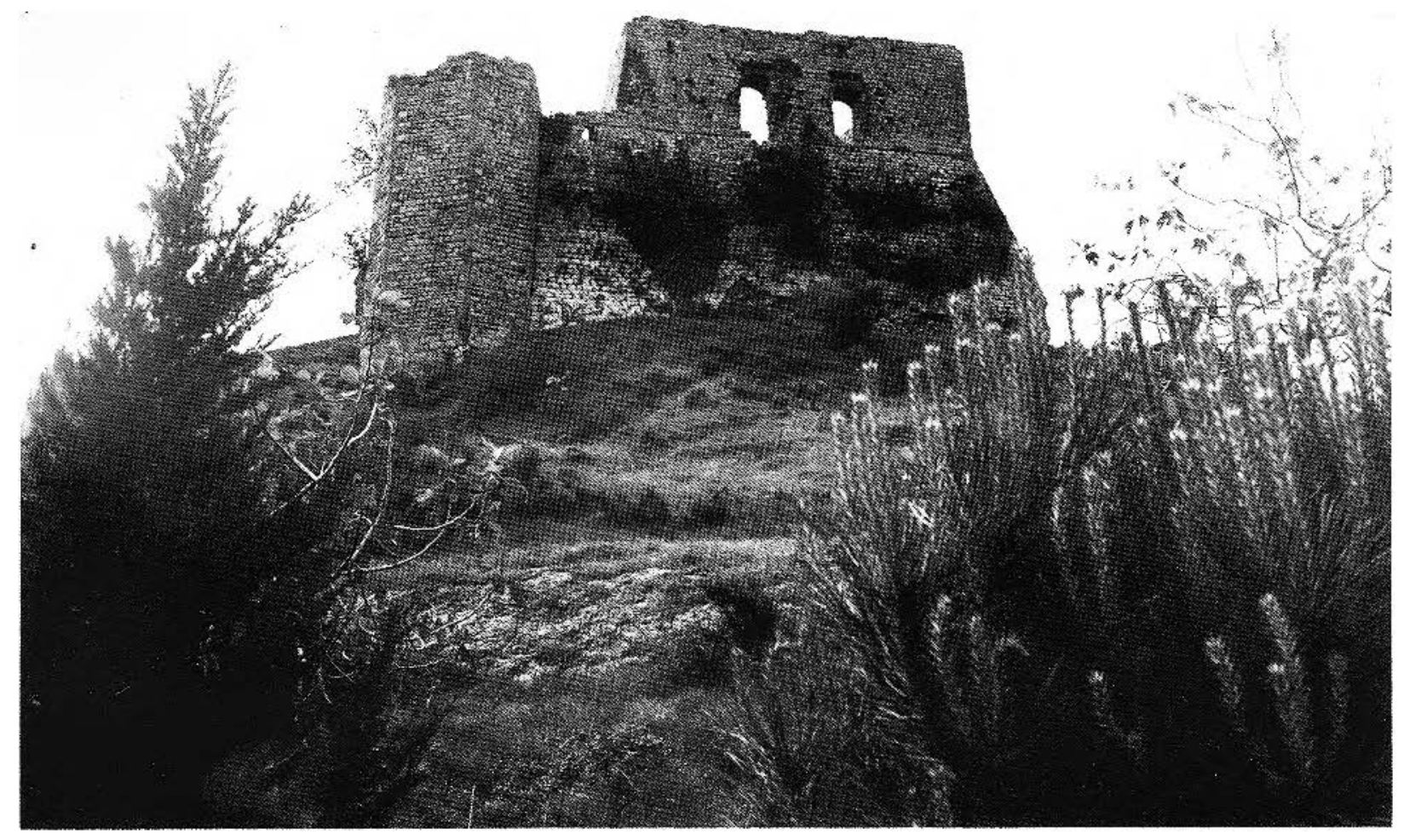

Figlri: 13. Montemassi, structure at the northwest of the fort seen from the northwest (Photo: Author).

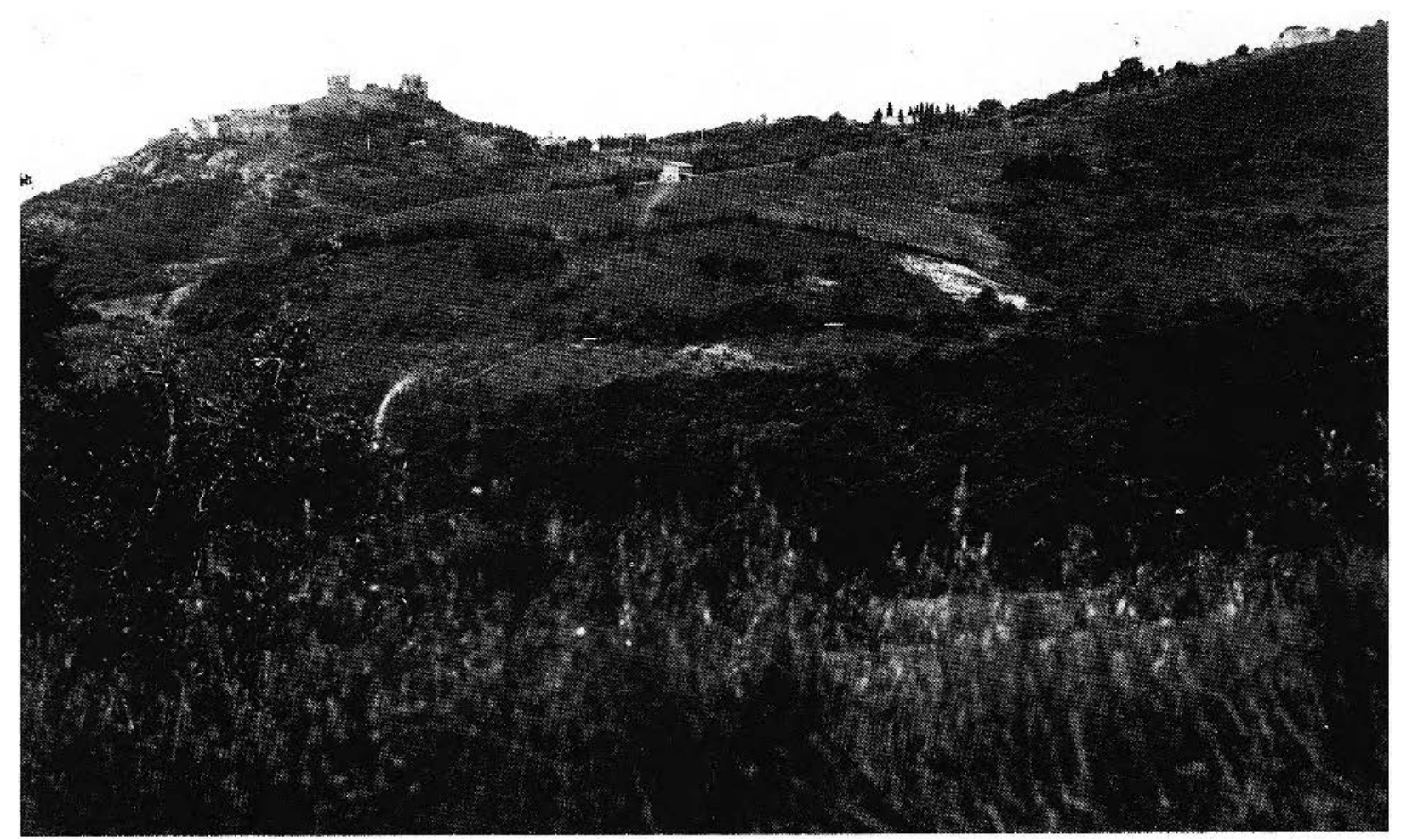

Ficurf: 14. Montemassi and surrounding landscape seen from the east (Photo: Author). 
Figure 15. Simone Martini, Snint Martin Renouncing the Use of Arms, Saint Martin Chapel, Assisi, Church of San Francesco (Photo: Alinari).
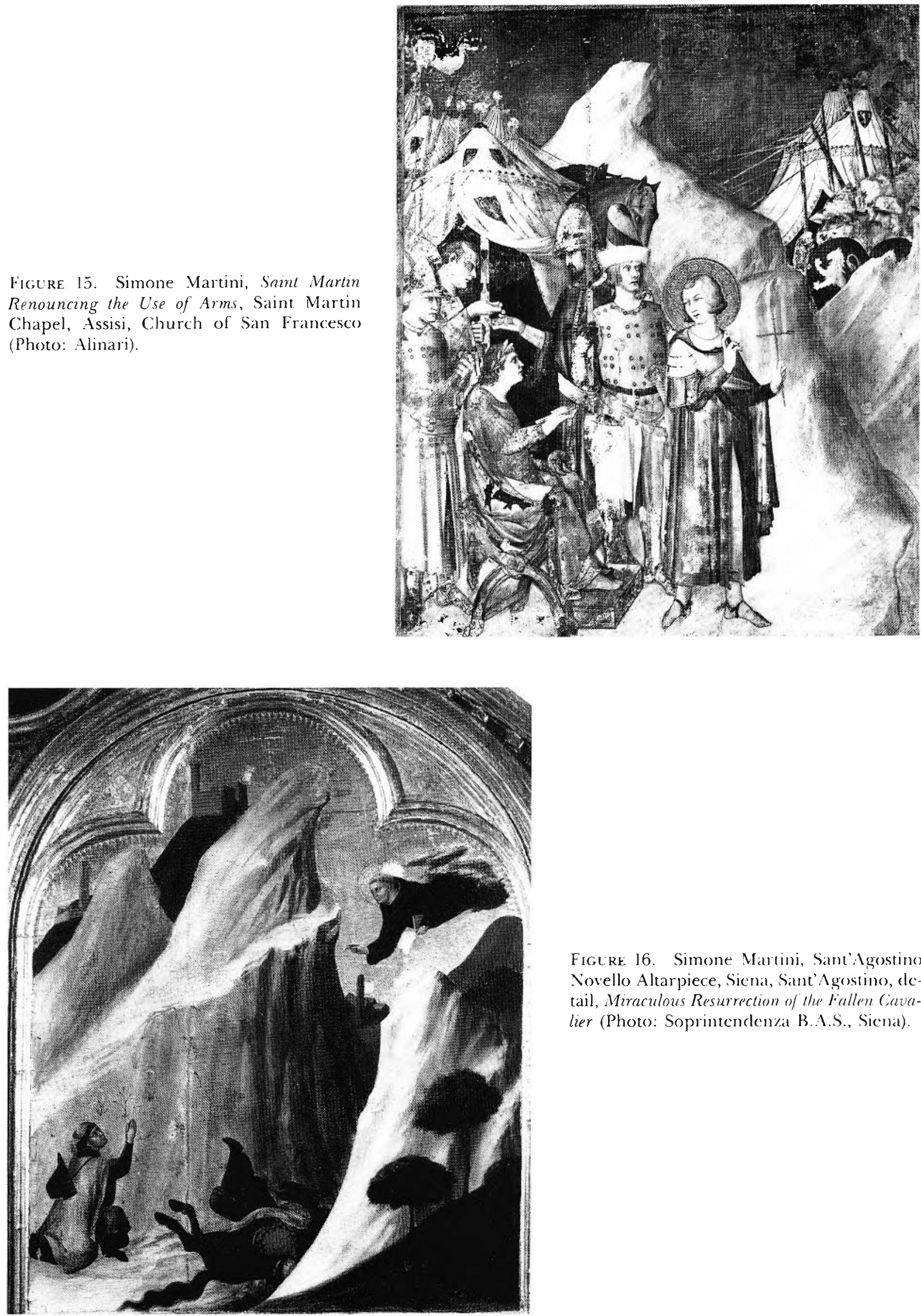

Figlre 16. Simone Martini, Sant'Igostino Novello Altarpiece, Siena, Sant'Agostino, detail, Miraculous Resurrection of the Fallen Ciavalier (Photo: Soprintendenzat B.A.S., Siena). 


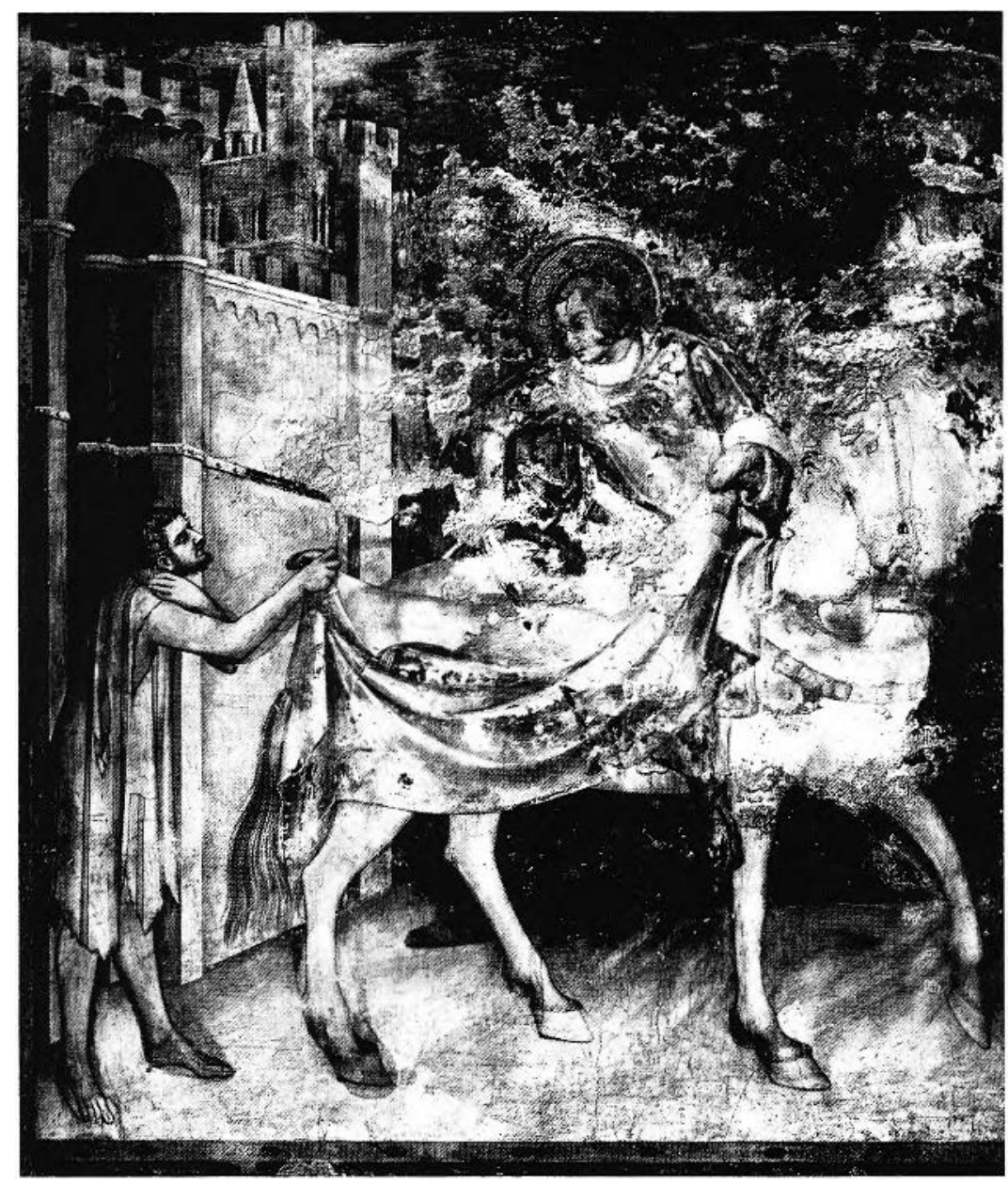

Figurt 17. Simone Martini, as in Fig. 15, Saint Martin Dividing his Cloak with the Beggar (Photo: Alinari).

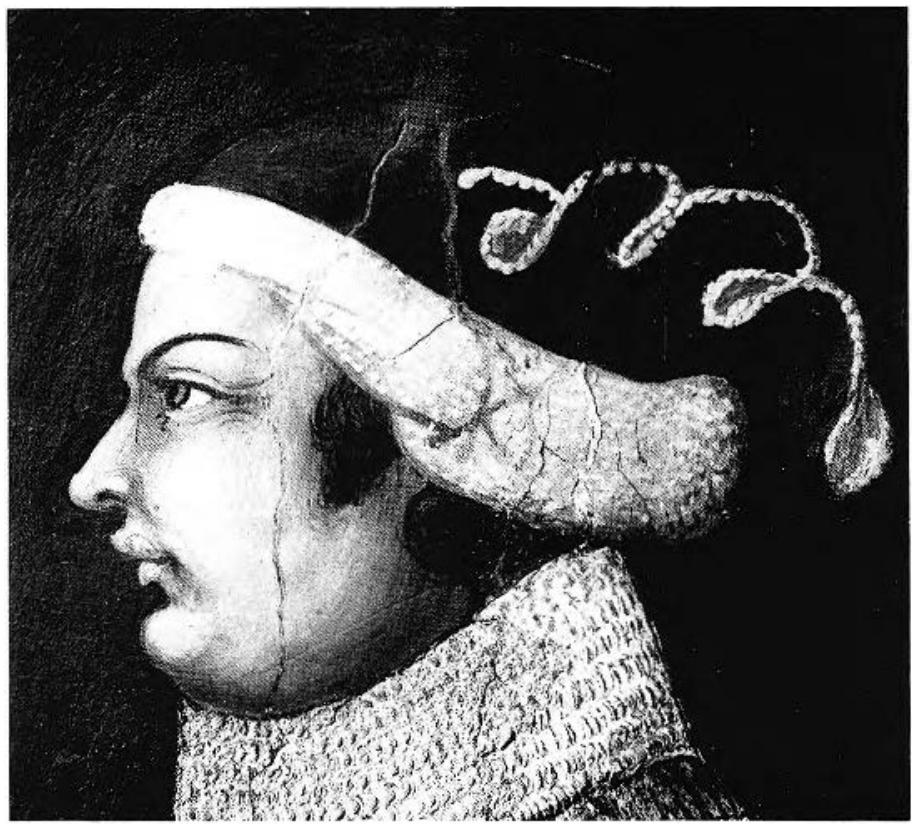

Figuke 18. Detail of Fig. 4, Head of Guidoriccio (Photo: Kunsthistorisches Institut florence). 


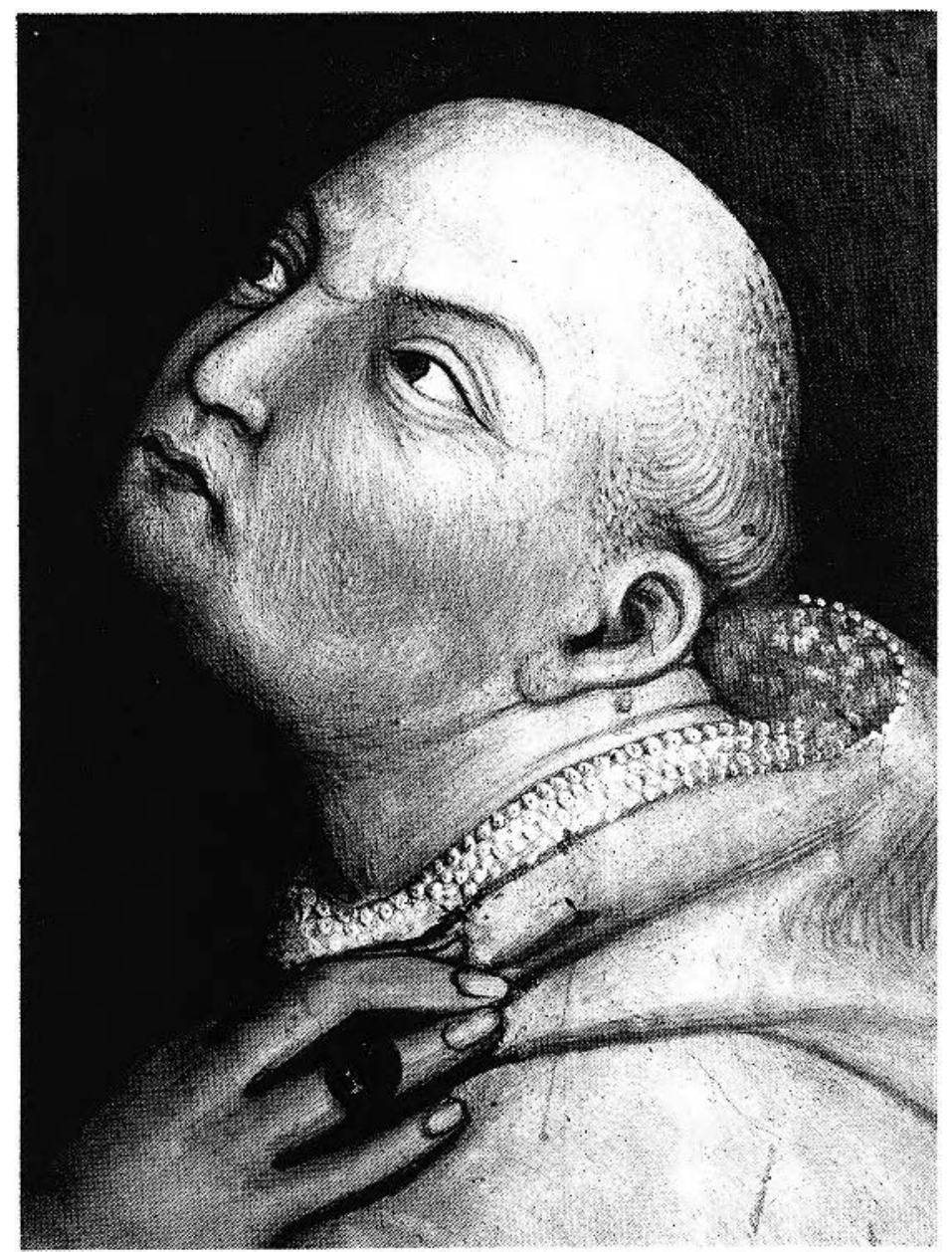

Figure 19. Simone Martini, as in Fig. 16, head of Cardinal Gentile Partino da Montefiore (Photo: Kunsthistorisches Institut Florence).

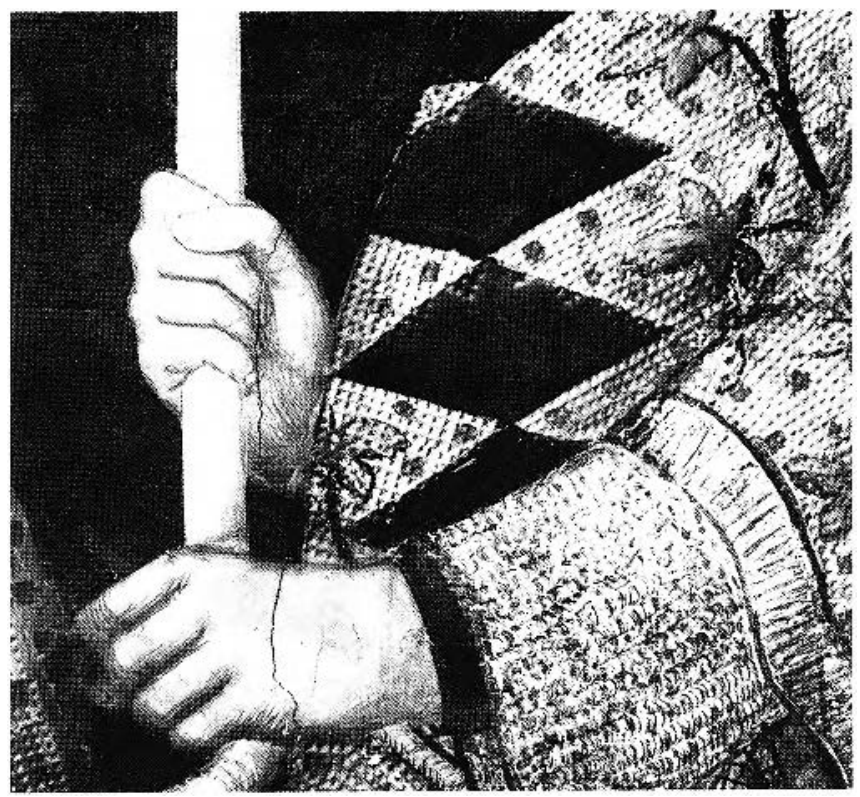

Fisitrf. 20. Detail of Fig. 4, Ilands of Guidoriccio (Photo: Kunsthistorisches Institut Florence). 


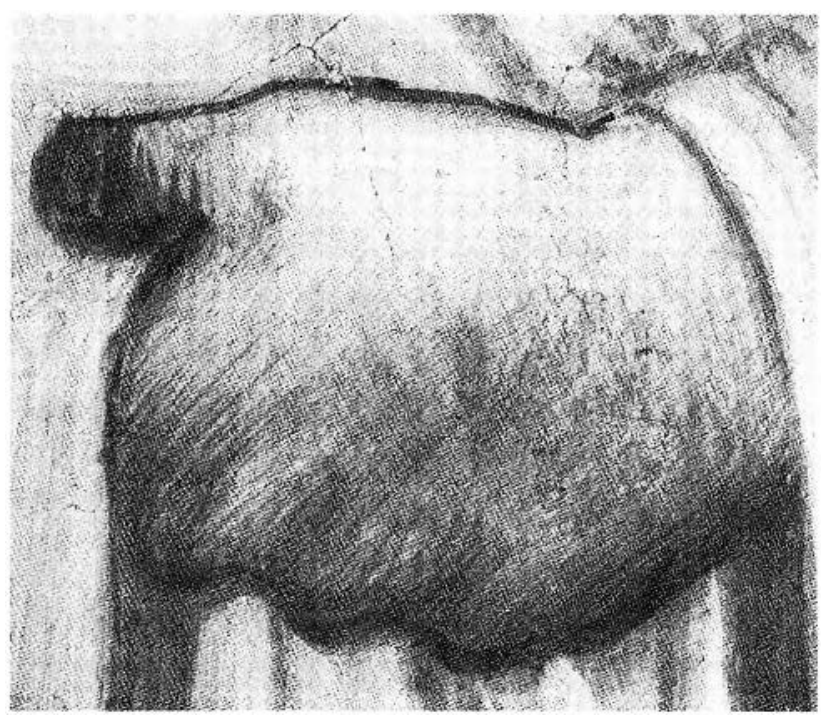

Figure 21. Simone Martini, detail of Fig. 17, detail of hand (Photo: Kunsthistorisches Institut Florence).

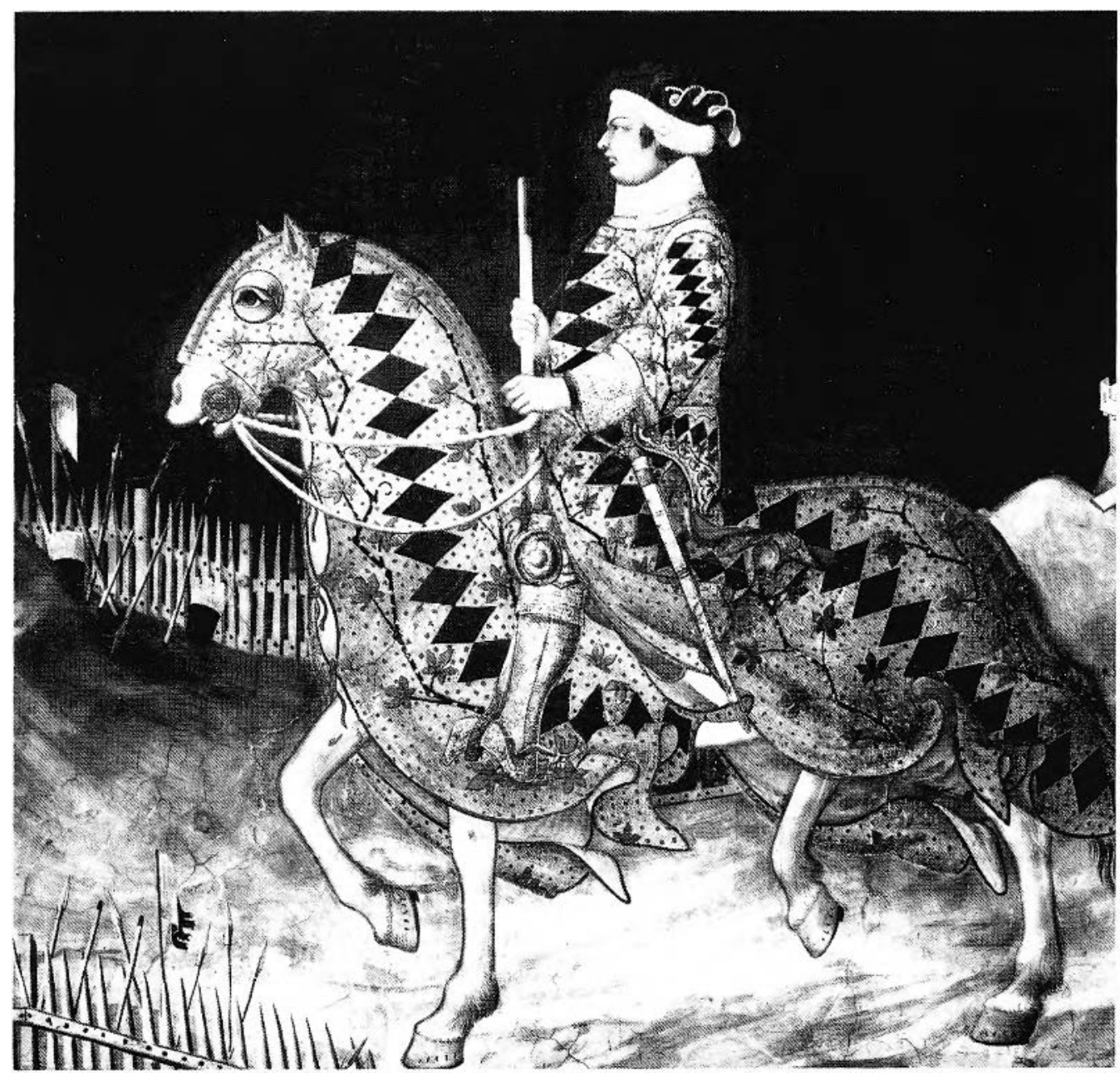

Figtre: 22. Dctail of Fig. 4, Equestrian Figure of Guidoriccio (Photo: Kunsthistorisches Institut Florence). 


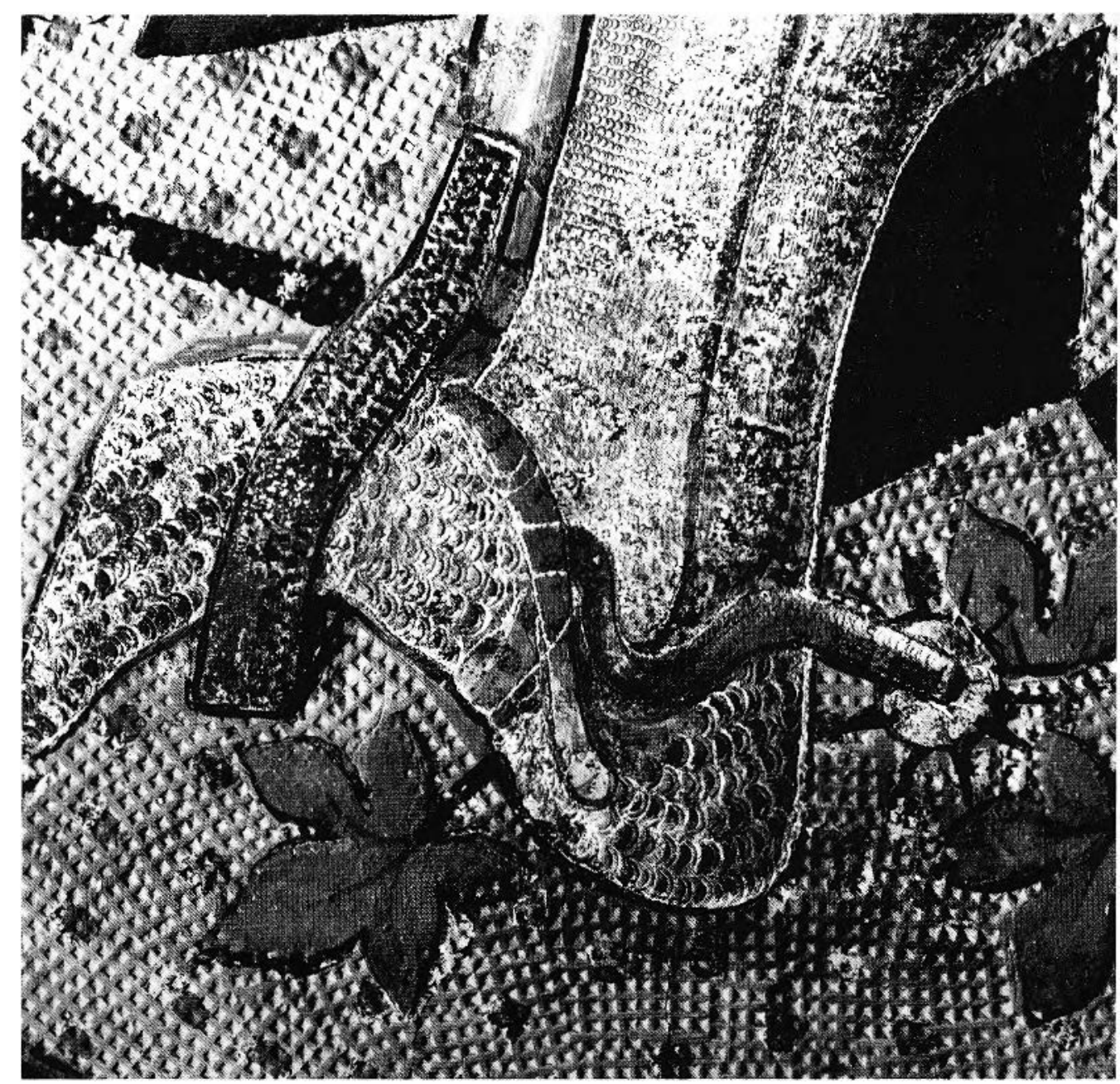

FIc:URe 23. Detail of Fig. 4, Detail of Equestrian Figure (Photo: Kunsthistorisches Institut Florence).

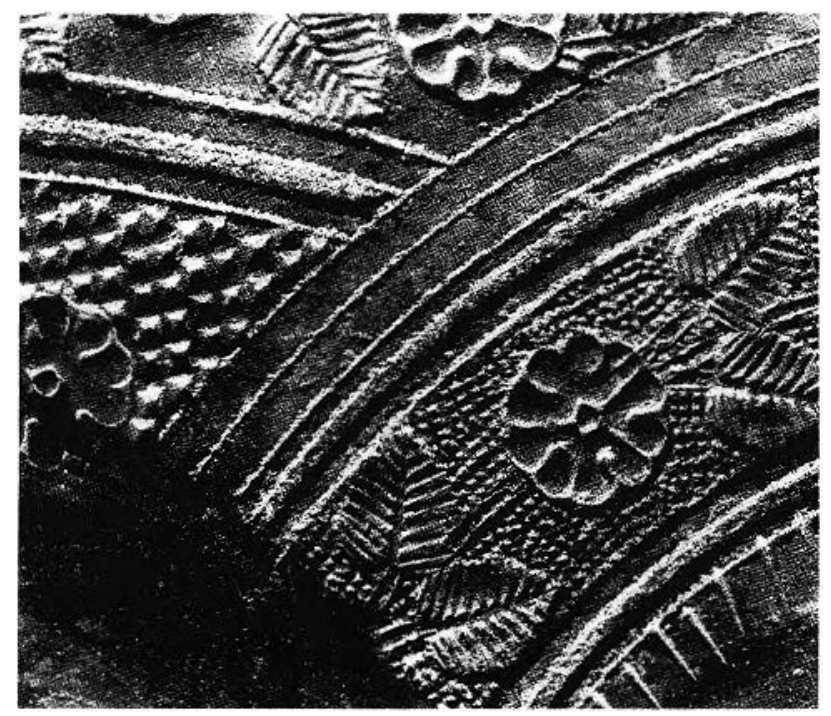

Figure 24. Simone Martini, Maestà, Siena, Palayzo Pubblico, I etail of the Lower Border Medallion with Saint Matthew (Photo: Author). 


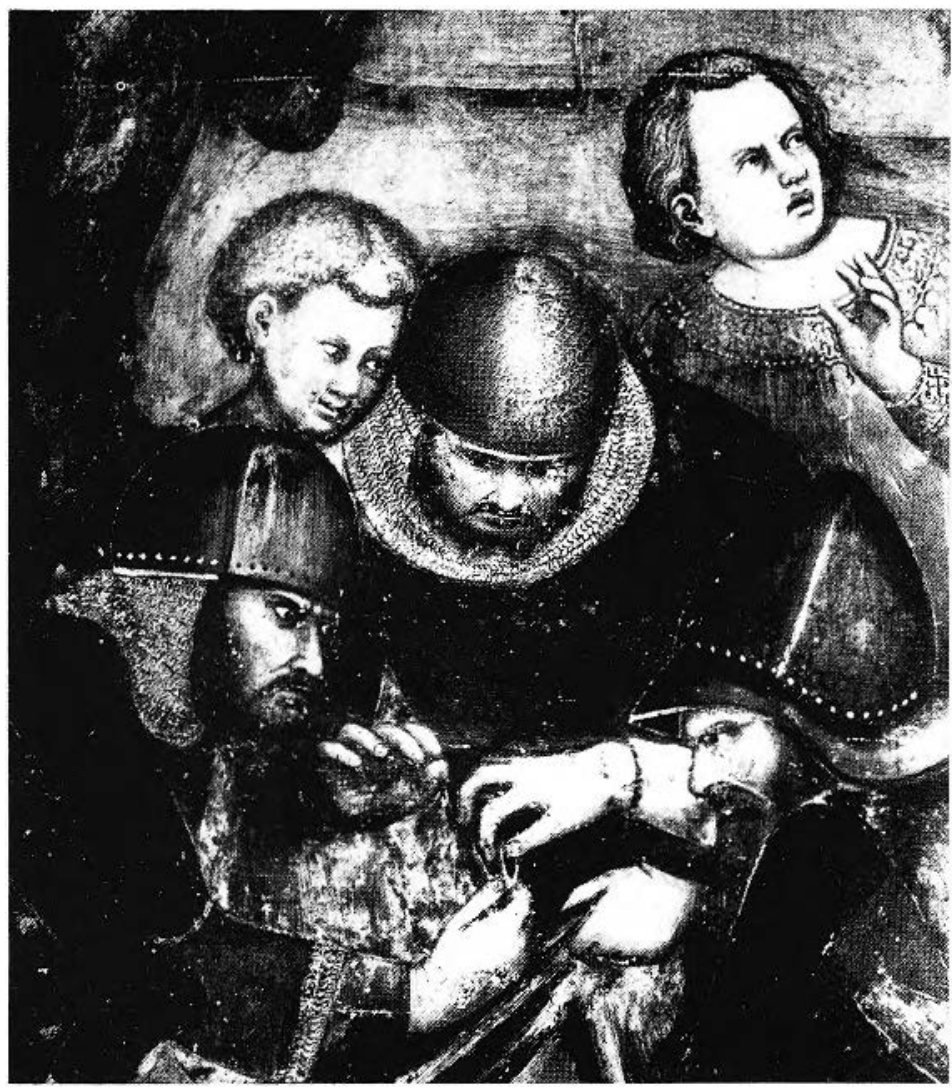

Figlere 2j. Barna da Sicna, Crucifixion, San (imignano, Collegiata. Detail of the Soldiers Beneath the Cross (Photo: Anderson).

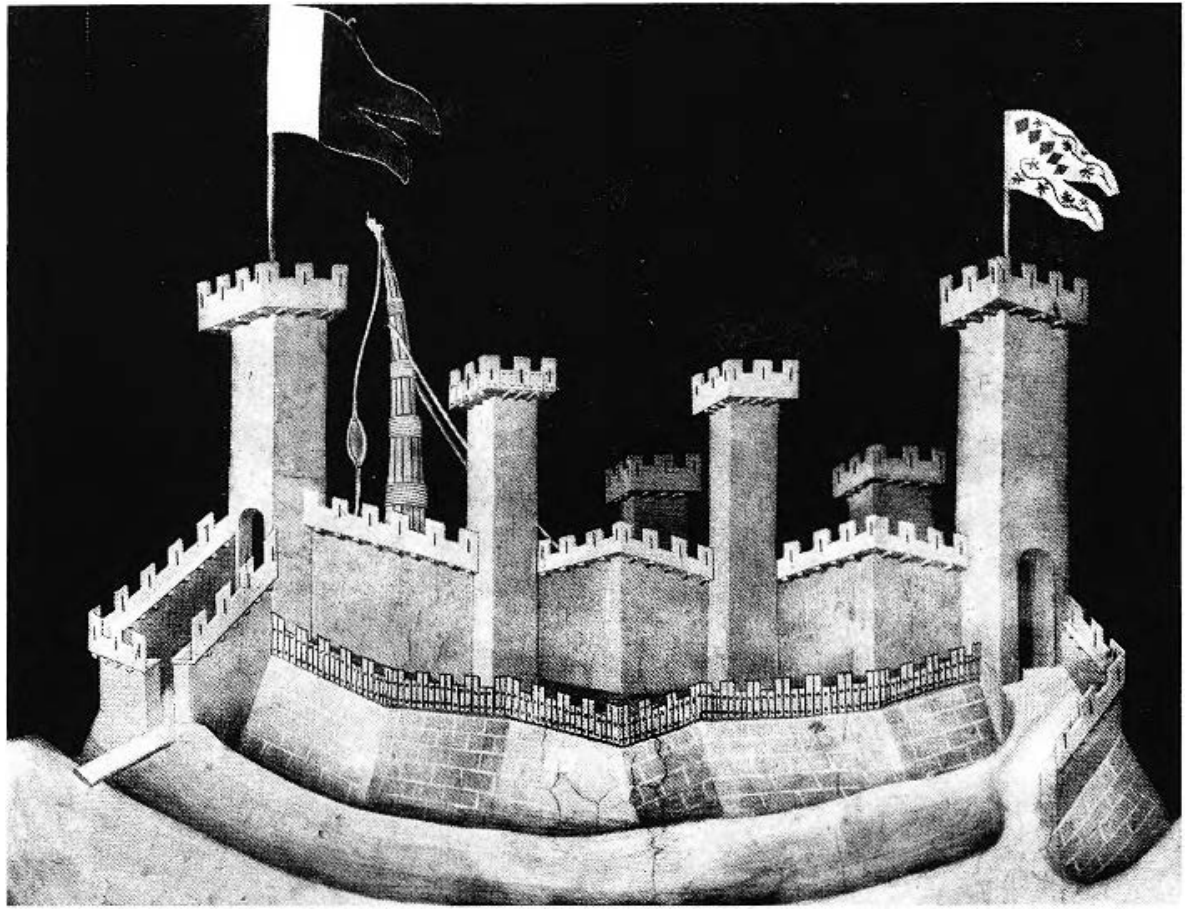

Figure 26. Detail of Fig. 1, Guidoriccio fresco. Detail of Montemassi (Photo: Kunsthistorisches Institut Florence). 


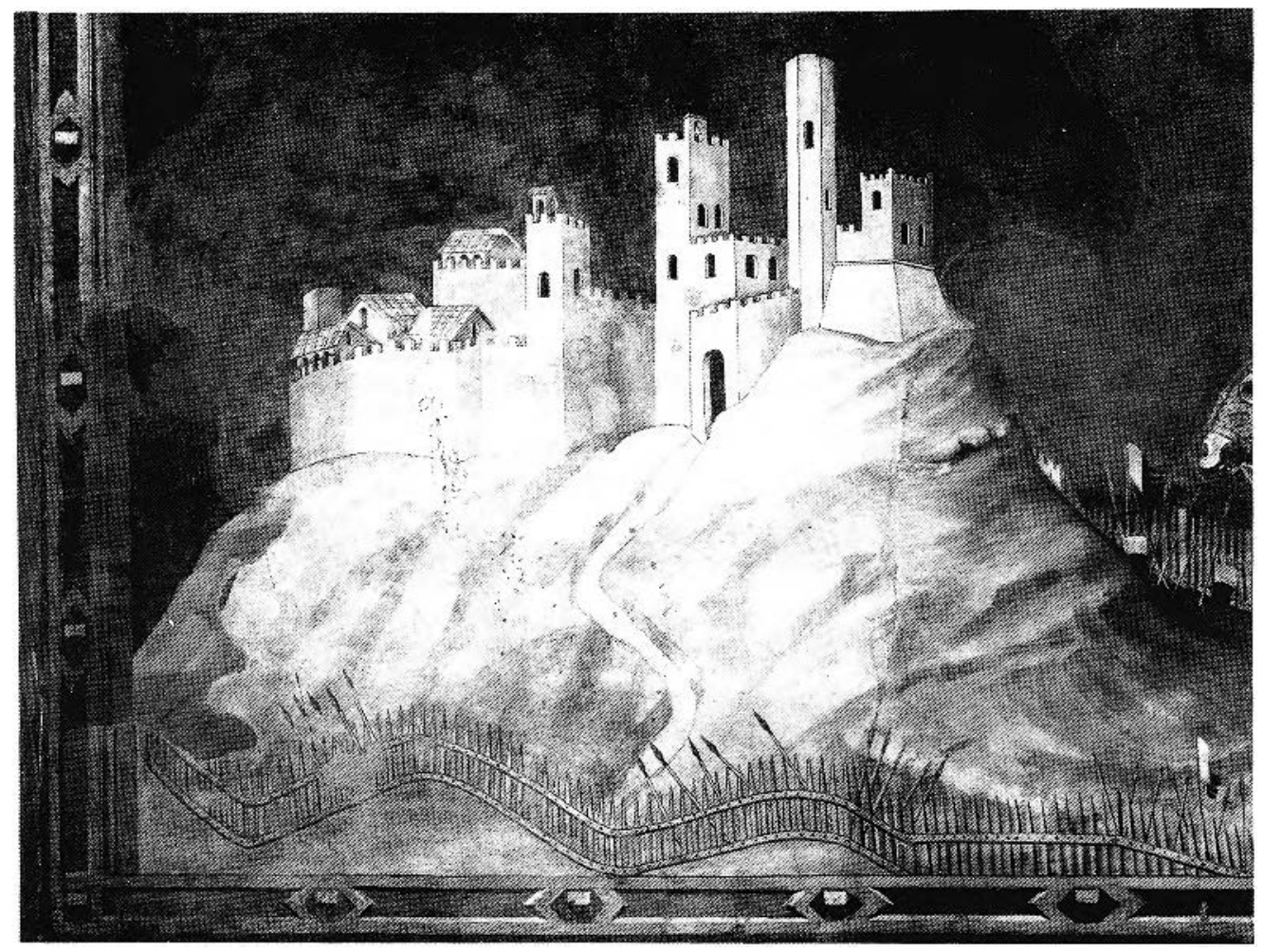

Figure 27. Detail of Fig. 4, Guidoriccio fresco. Detail of the so-called Battifolle. (Photo: Kunsthistorisches Institut Florence).

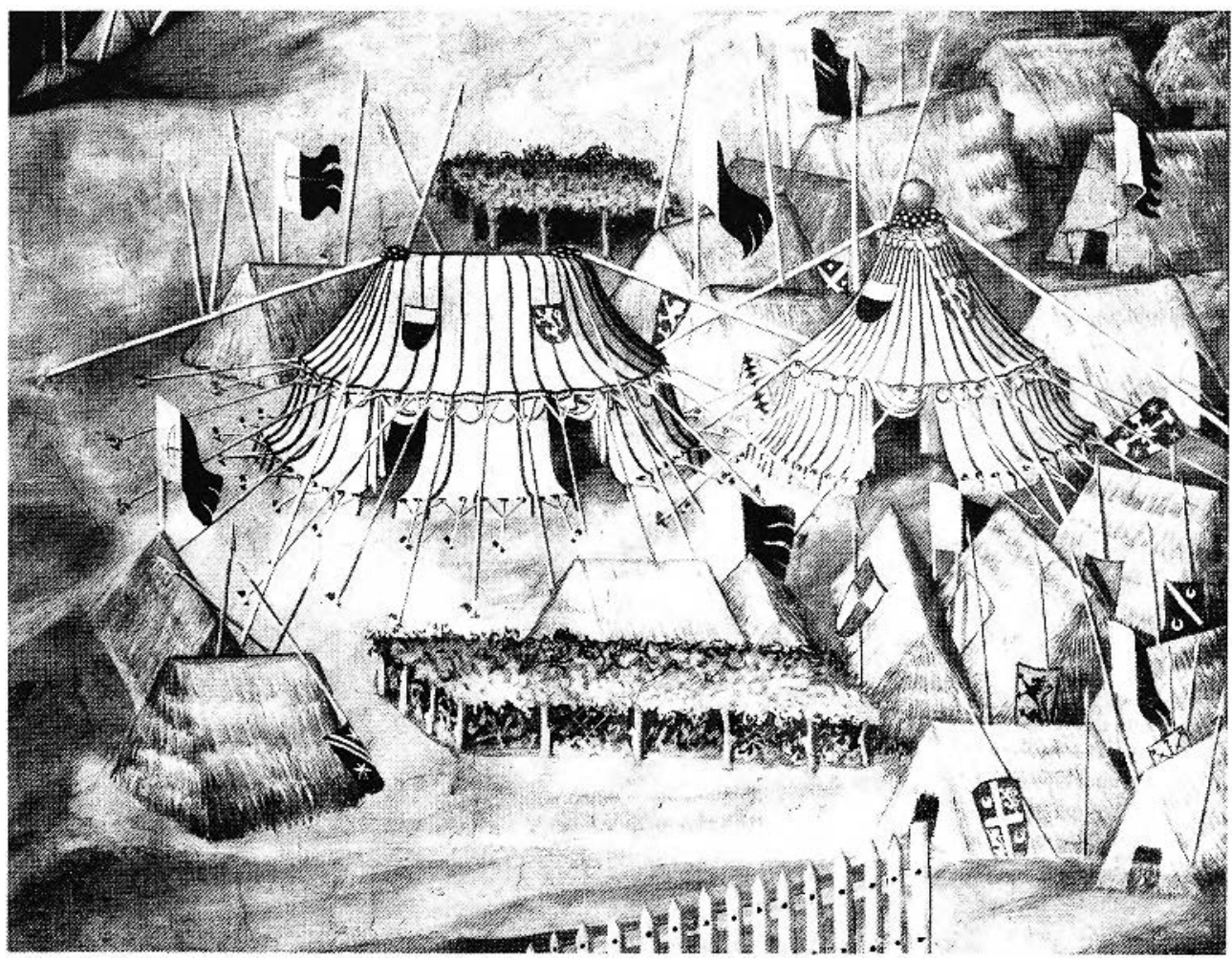

Figure 28. Detail of Fig. 4, Guidoricio fresco. Ietail of the Sienese Encampment (Photo: Kunsthistorisches Institut Florence). 


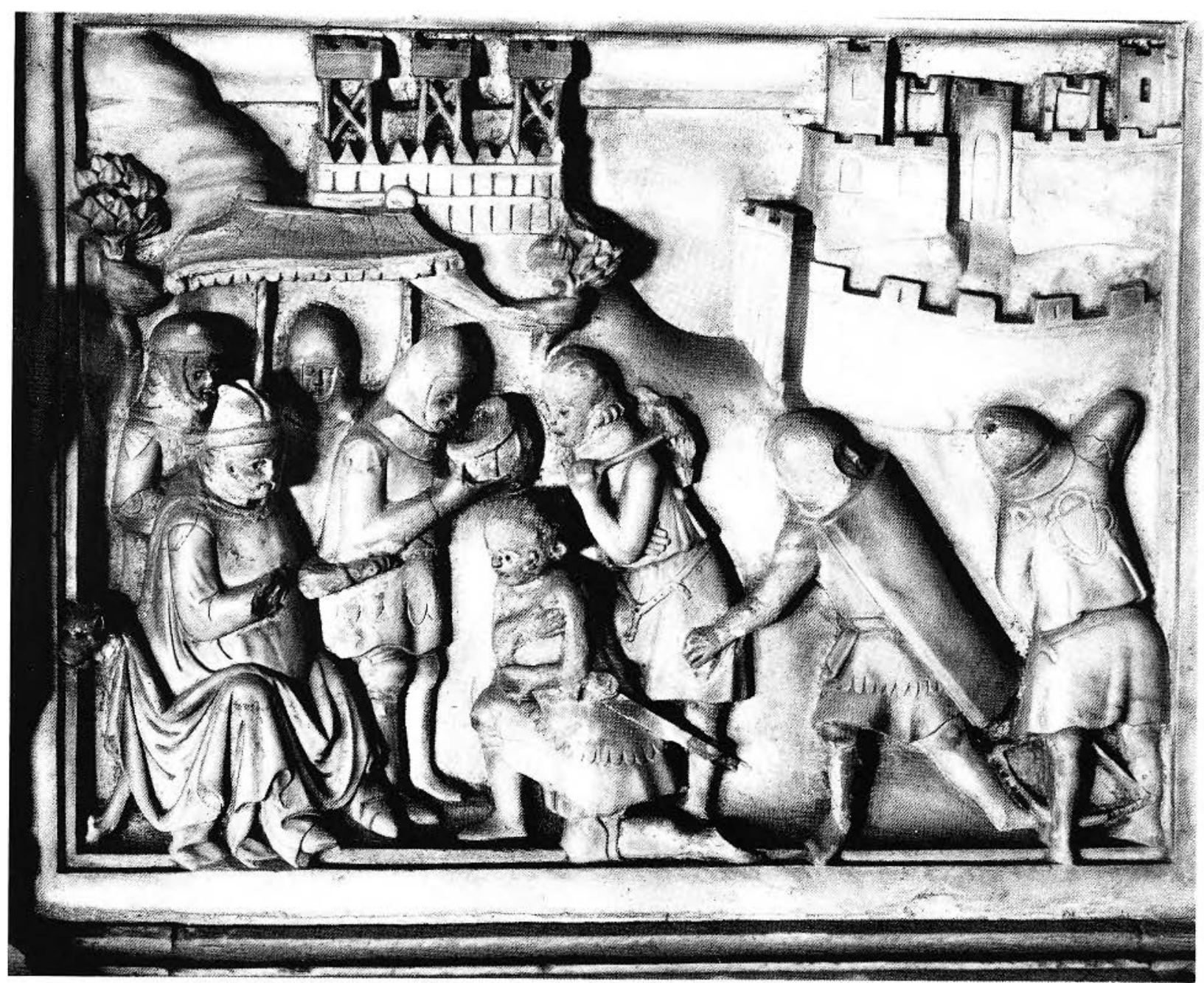

lisunr: 29. Tomb of Bishop Guido Tarlati. Arezzo, Cathedral. Detail of The Taking of ('hiusi (Photo: Alinari).

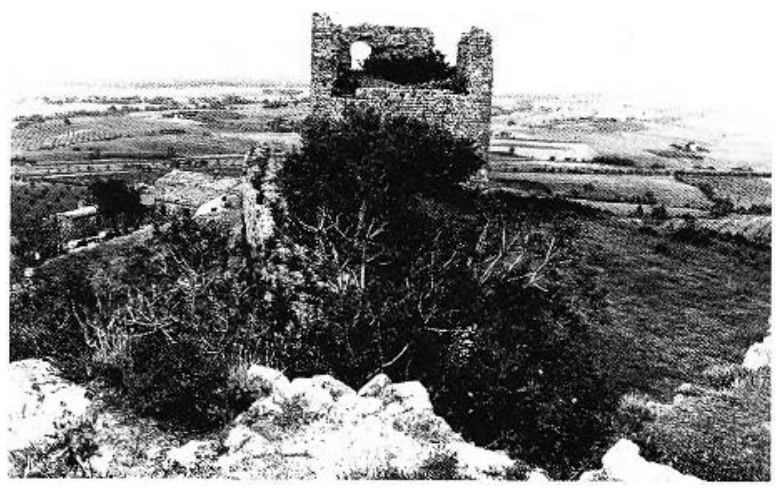

Figere. 30. Fort at Montemassi. The South Tower and Maremma behind, seen from the north (Photo: Michael Brat!ne).

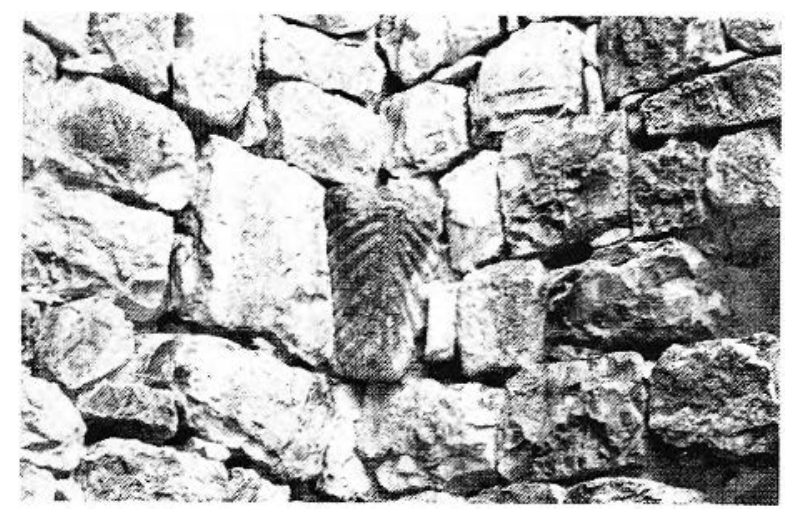

Figure 31. As in Fig. 30. Detail. Corbel (Photo: Author). 


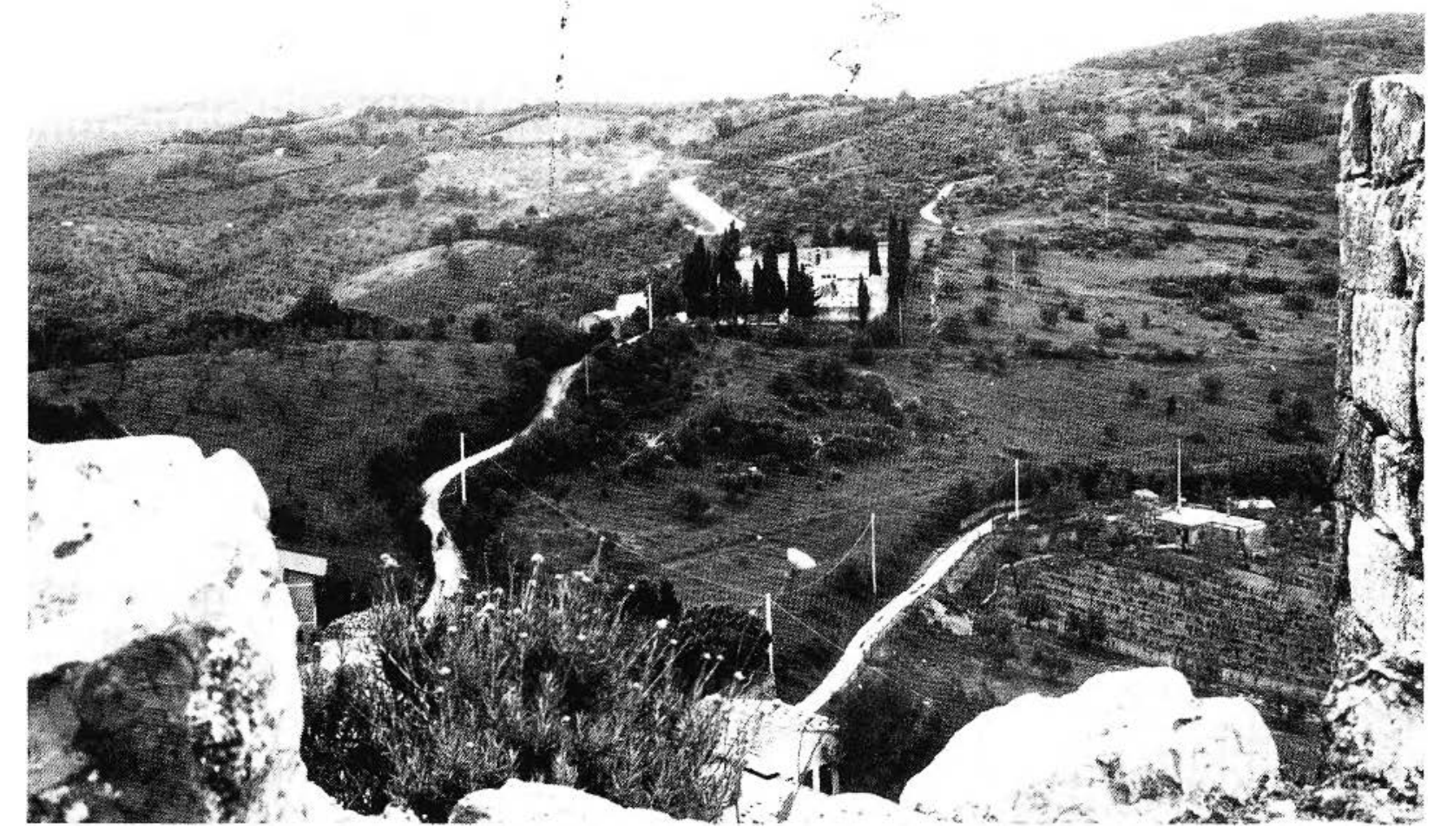

Fig;ikf 32. Diagram after map of Montemassi and surroundings (Photo: Carte d'lalia, folio 128).

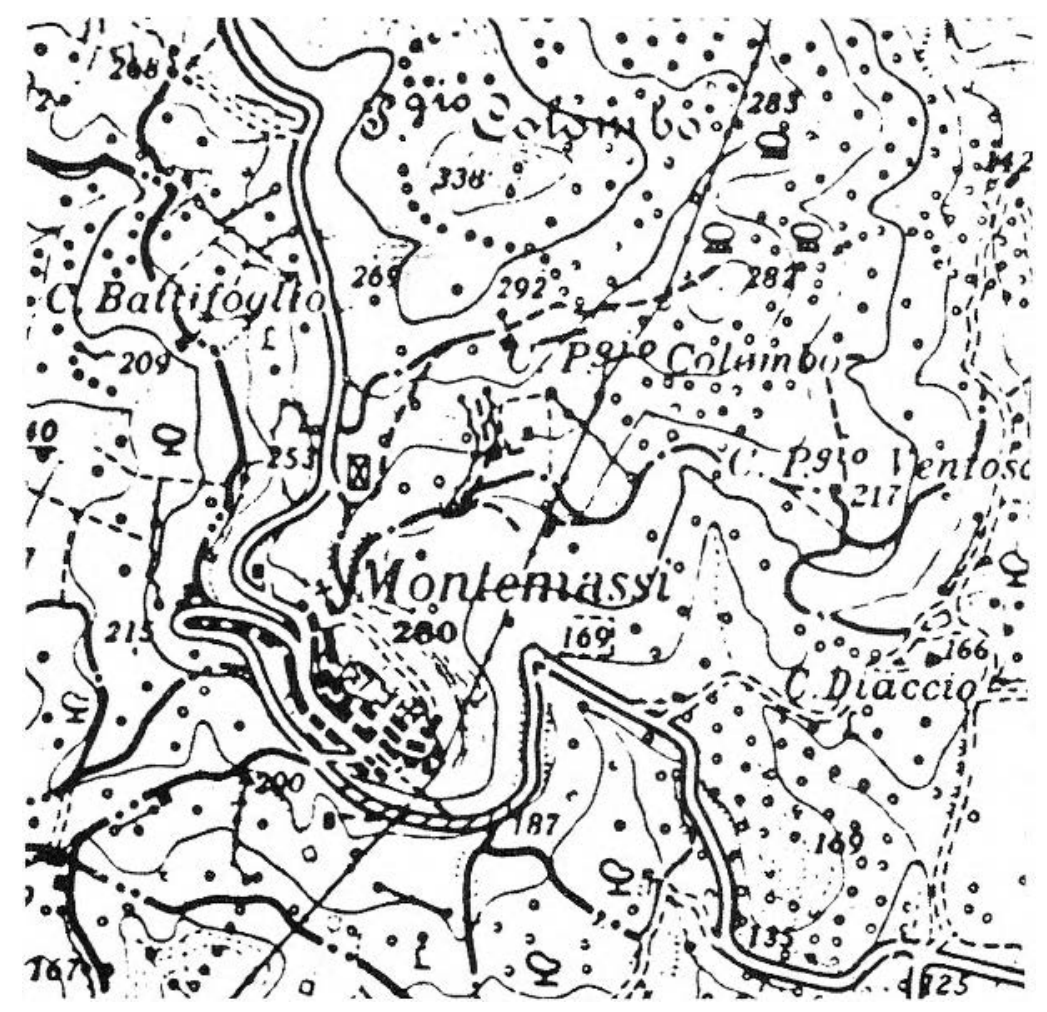

IIIGLRE 33. Ridge adjoining the fort at Montcmassi to the north, seen from the fort, with Poggio Colombo appearing at the upper right side (Photo: Author) 
territory. Following the painted landscape, he encamped his army at the top and flanks of Poggio Colombo, reasonably close to Montemassi, which could be reached from there within minutes. The first task he faced was to clear the terrain of the thick brush in order to assure mobility for his troops. Some of the terrain may already have been cleared for agriculture, as seems indicated by the painted field of grape, but otherwise the vegetation - the wild brush - was as thick and covered with thorn bushes then as it is now, and as infested with snakes. It was surely cleared along the defensive perimeter, which is defined on the fresco by palisades and ditches. ${ }^{108}$ This defensive perimeter would have extended from the Sienese camp on Poggio Colombo, following both flanks of the connecting ridge, to around Montemassi, conforming to the palisade fence on the fresco. The beige barrenness of the painted landscapewhich contradicts the actual lush green vegetation all around - would represent the cleared ground, except for the fields of grape, which the Sienese would have found there and left intact; ${ }^{109}$ the very barrenness of the painted landscape refers directly to the siege. However, it should be remembered that Simone Martini's landscapes, with the exception of the green vegetation of the Virgil allegory in the Ambrosian Library, are generally beige and barren. ${ }^{110}$ Where did Guidoriccio, prob-

108 Agnolo di Tura (in Muratori, Rerum italicarum scriptores, cronache senesi) mentions the "grandi stecati intorno [a Montemassi]."

109 The vigna has created more spilled ink than it deserves. Mallory and Moran have underscored (most recently again in Burlington Magazine [A pril 1986], 250) n. 4) that Agnolo di Tura's references to the vigna, meaning field of grape, at the siege of Montemassi clo not make good sense. When he first refers to the siegc he writes as follows: "La detta oste a Montemassi vi stc gran tenpo, in Inodo che quelli dell'oste posero una grande vigna in canpo, ed ebero del vino di quella vigna in canpo" (in Muratori, Rerum italicarum scriptores, cronache senesi, 464). He is equally confused when he refers to the field of grape at the termination of the siege: "eravi stato l'assedio sette anni, che vi posero le vigne" (in Muratori, Rerum italicarum scriptores, cronache senesi, 478). In fact, the siege lasted only seven inonths and cleven days. Here the chronicler confused months with years. Mallory and Moran have insisted that the fifteenth-century compiler and editor of this chronicle confused vigna meaning field of grape with vigna meaning war machine used at sieges (concerning the relative reliability of the chronicle, which has to be read with carc, see Lisini's preface, in Muratori, Rerum italicarum scriptores, cronache senesi, $\mathrm{xx}$; but see also W. Bowsky, in Speculum, $x \times x i x$ [1964], 3ff.). (Of course, the situation changes if the Guidoricio fresco is indeed by Simone Martini, for then the fifteenth-century editor of Agnolo's chronicle would have considered the fresco itself prime evidence. The fresco would have informed him that there were indeed fields of grape near Montemassi.

110 See, for example, Simone Martini's beige and barren landscapes in the Saint Martin Chapel and on the Sant'Agostino Novello Altarpiece (Figs. 15-16). ably advised by Pietro di Lando, locate the battifolle? I suspect he did so quite close to the fort on the highest point along the northern ridge, on a rise now covered by an olive grove, across the way from the cemetery (Fig. 33). ${ }^{11}$ To the west the ground dips sharply into the valley and the road presently running from Montemassi to Roccatederighi. Seen from the east, this hill would conform in its position within the landscape to the one supporting the turreted walled structure on the fresco.

\section{THE PAINTED BATTIFOLLE}

We have already noted that the real battifolle could hardly have corresponded to the painted one. Accordingly, this painted fortress deserves closer scrutiny. (On top of a hill there is a crenellated wall sectioned by towers, set on a scarped base rising from a ditch. This wall, seen from somewhat below, is polygonal in shape. Four towers are evenly spaced along the front, while two other towers, partially visible in the distance, belong to the wall's unseen distant side. The only structure visible within the walled space is a catapult. This emptiness within is surprising. Frequently, although not always, medieval forts or castles include major interior structures. This empty turreted wall brings to mind the present view of Monteriggioni from the autostrada below, with the few buildings within barely visible. One recalls Dante's reference to its impressive walled perimeter. ${ }^{112}$ Frederick II's castle at Prato consists of a rectilinear towered wall surrounding an open court. The emptiness within the walled perimeter of the painted fortification may be partially reliable since, in the short time available, no major structure of ashlar masonry could have been erected.

Let us consider the front wall: the four near towers, being evenly spaced and seen consistently from the same side angle, have a flattening effect. The side towers contain the entrances and they are much larger than the two set between them. Considered as a unit, the visible portion of the wall projects forward towards the centre. This forward projection is defined by the downward curve of the ditch and of the scarped bank below the wall. Its forward projection is, however, partially ambivalent. The wall sections between the towers are

111 Martindale concurs ("The Problem of "Guidoriccio," 262 n. 35). Italo Moretti (in Prospettiva, xxin [October 1980)] disagrees, placing the battifolle in the valley to the west of this ridge about midway between Montcmassi and Poggio Colombo, some five hundred metres from Montcmassi, at the site of a farmhouse which still bears the name "casa battifoglio." In military terms this location is not acceptable.

112 Dante, Inferno, xxxi, 41. 
not consistently rendered. The one at the left side is straight, whereas the other two project forward from the sides forming a corner at the centre. Their angular projection is taken up by the scarped embankment below (the embankment also projects forward in a similar manner at the left side). These angular wall projections make little sense from a military viewpoint, since towers should have been located at the projecting corners, reinforcing them. The two visible entrances are protected following medieval tradition. The approach to the entrance in the right tower is channelled for some distance between the escarpment supporting the principal wall and an outer wall segment connected to the entrance tower. And the other entrance is preceded by a walled court, preceded in turn by a bridge crossing the ditch. The entrance preceded by a walled court was commonplace and is still found: witness the Porta Romana in Siena, or the city gates on Fra Angelico's Deposition from the Cross in the Museo di San Marco. A similar, albeit more intricate, medieval city gate actually survives in Montagnara. ${ }^{113}$ Such examples abound.

At the base of the towered wall extends a wooden fence which is rendered in some detail. This fence is set at the same level as are the entrances to the walled precinct. They would define the ground level on which the turreted wall rests within. The scarped embankment below is surfaced with dressed stone. At the extreme right side where there is no ditch the scarped hillside is similarly surfaced. Such scarped embankments or bases of ashlar masonry are often found in medieval Italian fortifications: witness the scarped base of the tower at Radicofani, ${ }^{114}$ or below a portion of the cassero at Montemassi (Fig. 27). The embankments supporting the fifteenth-century castle of Torrechiara near Parma are also scarped and surfaced with ashlar. ${ }^{15}$ On both fragmentary landscape paintings by Ambrogio Lorenzetti in the Pinacoteca in Siena the towered fort is set on a scarped base. ${ }^{116}$ Simone Martini might have seen ambitious scarped embankments of dressed stone when he was in southern Italy. The scarped base of the Castelnuovo in Naples surely belongs to its original Angevin construction. ${ }^{117}$ An interesting com-

113 Reproduced in many authors, Monumenti d'Italia, I Castelli (Novara, 1978), 132f

114 Reproduced in many authors, I castelli del senese (Siena, 1976), I, 144, and II, 359f.

115 Reproduced in R. Greci, M. di Giovanni Madruzza, and G. Mulazzani, Corti del rinascimento nella protincia di Parma (Turin, 1981), 1092 fig. 100; see also certain fortresses with such slanted ashlar foundations represented in the fresco) decoration of the same castle (in Monumenti d'Italia, 1.57).

116 Reproduced in Piero Torriti, La Pinacoteca di Siena, i dipinti del xii al xv secolo (Genoa, 1977), $114 \mathrm{f}$.

117 Concerning the Angevin origin of the eastern side of the parison is found in the Angevin precinct wall of the fortress at Lucera, with its regular angular projections corresponding substantially to those evident on the scarped base of the painted fort. ${ }^{118}$ The base of Frederick II's palace at Lucera is also scarped -indeed, its scarped ashlar base is all that remains of it. ${ }^{119}$ Scarped embankments surfaced with ashlar stone are frequently found among the great medieval fortifications in Europe and those erected by the crusaders in the Near East: witness, for example, the Krak des Chevaliers or the fortifications at Acre.

The battifolle on Simone's fresco is a composite of structural elements, some of which reflect elaborate permanent architecture in stone, obviously incompatible with what a contemporary quickly-raised military fortification could have looked like. It also includes elements of wooden construction: the crenellated passages along the walls and the crenellated platforms on the towers. Witness the wooden beams extending forward from the walls, the wooden planking, and the nail heads. The use of such wooden components on top of stone walls was quite common in medieval Italian fortifications. ${ }^{120}$ See, for example, the wooden crenellated platform surmounting the tower of the fortified house on the new fresco (Fig. 9). In summary, to consider this painted turreted walled precinct a reliable guide of what the battifolle at Montemassi actually looked like simply does not make good sense.

Moran and Mallory have proposed that this painted fortification, according to its appearance, cannot belong before the quattrocento; they contend that its scarped ashlar base reflects a new type of fortification introduced during the Renaissance to cope with the unprecedented firepower of the cannon. ${ }^{121}$ Indeed, defensive military architecture was revolutionized by the advent of the cannon on a wider scale in warfare beginning, approximately, with the later quattrocento. Until that time the high vertical walls of medieval fortifications had offered sufficient protection, but they were doomed by the cannon's firepower, and a new type of fortification was devised in order to resist its powerful lateral trajectory. Walls were lowered and thickened, and they were scarped in order to lessen the impact of the striking cannon balls. The

Castelnuovo see F. Ferrajoli, I castelli di Napoli (Naples, 1964), 12f., 50; he also comments on the similarity of the scarped walls of the Castelnuovo with the ancient (ireek city wall of Naples.

118 Reproduced in Monumenti d'Italia, 437 If.

119 Reproduced in Monumenti d'Italia, 437.

120 See M. Braune, Türme und Turmhäuser in Toskana (Co)logne. 1983), 26f.; also verbal information.

121 Michael Mallory and Gordon Moran, in Studies in Iconography, viI-viII (1981-82), 3f. 
ditches before the walls were widened and so were the passages on the walls, which were also strengthened so that they could support the rapid movement of troops and artillery about the defensive perimeter. At the corners of the new type of fortress - whether rectilinear or polygonalbastions reached outward in sharp triangular formation, so situated that all exterior parts of the defensive walls could be observed and controlled from within. The bastion became the essential feature of the modern fortress type. This change from the medieval to the modern fortress has been aptly summarized as moving from the difesa piombante to the difesa fiancante. ${ }^{122}$ Tuscany abounds with remarkable early examples of the new fortress type: witness those at Poggio Imperiale near Poggibonsi, at Volterra, and at Sarzana. ${ }^{123}$ To connect this new type of fortress with the turreted walled structure on the Guidoriccio fresco is impossible. The high vertical turreted crenellated wall, the approaches to the entrances, these are all still typically medieval. The scarped base of ashlar supporting the fortress cannot be confused with the scarped modern fortress.

From what has been considered, it is clear that the painted turreted walled precinct is a creation of Simone Martini's imagination. It stands to reason, as already stated, that this fortress was intended to represent Sicna's defensive military power. This image was not fortuitous. Here Simone substantially followed a well-cstablished tradition, dating back to classical antiquity, of the turreted city wall representing city or state. Witness the vignettes of citics so depicted on ancient coins $^{124}$ and in the carly medieval corpus agrimensorum manuscripts. ${ }^{125}$ The towered city wall also assumes the role of the civitas dei in early medieval psalter illustrations ${ }^{126}$ and of biblical cities like Emmaus in the Codex Egberti. ${ }^{127}$ Even the Heavenly Jerusalem adopts this schemc: witness the sarcophagus of Saint Ambrose in Milan ${ }^{128}$ or its rendering in the Beatus Revelations manuscript series. ${ }^{129}$

122 Luigi Marini, in Francesco Marchi, Archilettura militare (ed. Rome, 1810), 14ff.

123 Reproduced in Monumenti d'Itulia, 194ff., $200 \mathrm{ff}$., and 22()ff.

124 Sec E. B. Smith, Architectural Symbolism of Imperial Rome and the Middle Ages (New York, 1978), figs. 28, 50, etc.

125 Sinith, Archilectural Symbolism, figs. 55-57, 59, and 60

126 Sec in particular the many turreted city walls appearing in the illustrations of the Utrecht Psalter reproduced in E. ' $\Gamma$. Dewald, The Illustrations of the Utrecht Psalter (Princeton, ...., 1932), pls. 21, 26, 40, etc

127 Reproduced in W. Braunficls, Mittelalterliche Stadtbaukunst in the Toskana (Berlin, ed. 1979), fig. 4.

128 Reproduced in W. F. Volbach, Frühchristliche Kunst (Munich, 1958), pls. 46-47

129 See the many examples reproduced in La Jerusalemme Celeste, Milano, Università Cattolica del S. Cuore. 20 maggio5 giugno, 1983 (Milan, 1983), $149 \mathrm{ff}$
The turreted city wall is adopted by Dante in his Divine Comedy to define topographical units and eschatological territories. Dante enters the inferno through a city gate. ${ }^{130}$ His elysian fields sheltering the great personages of classical antiquity are contained within seven concentric walls. ${ }^{131}$ And early Renaissance book illumination adopts this city wall scheme for sheltering paradise ${ }^{132}$ and Rome. ${ }^{133}$ Simone Martini's fortress was well chosen to symbolize the military preparedness of the protoRenaissance Tuscan commune on which its security depended. A similar idea, albeit serving a more realistic and intricate image of Siena, is expressed by the winged personification of Securitas which appears above its city gate in Ambrogio Lorenzetti's Pace on the opposite side of the same wall.

\section{CONCLUUSION}

The mountain hamlet on the new fresco dates from considerably before Guidoriccio. It certainly does not represent Arcidosso. The Guidoriccio fresco follows the basic "rules" of contemporary history painting in Tuscany: topographical "truth" combined with symbolism and contemporaneity of production with the event represented - the siege of Montemassi. It is coeval with the date it bears, 1328. Indeed, it was surely painted in a hurry between 28 August, the date of Montemassi's capitulation, and the triumphal return of the Sienese army on 10 September. Given this circumstance Simone Martini's composition is a remarkable achievement. Its very survival indicates that it was so perceived throughout the centuries up to the present. However, the survival of Simone's outstanding fresco in its prime location in the Palazzo Pubblico must have been determined essentially by the greatness of the defeated enemy. He was no other than Castruccio Castracani, the scourge of the Tuscan Guelphs, allied with the German emperor, their traditional foe. Castruccio's military fame long outlived him. He was the only Tuscan general whom Machiavelli idealized. ${ }^{134}$ We recall that earlier in the same

130 Dantc, Inferno, III, 2: "Per me si va ne la città dolentc."

131 Dante, Inferno, iv, 6.

132 See the Creation miniature in the Très Riches Heures du Duc de Berryat Chantilly, reproduced in I. Lognon, R. Cazelles, and M. Meiss, The Très Riches Heures du Duc de Berry (New York, 1969), page number not indicated

133 See the miniature representing Rome with its turreted polygonal wall in the later fourtcenth-century French manuscript of Henry Romain's Gestes et faits des unciens in the sächsische Landesbibliothek in Dresden (Ms. Oc.77; reproduced in E. Rothc, Medieval Book Illumination in Europe: The Collections of the German Democratic Republic [London, 1968], pl. 68)

134 Machiavelli, "La vita di Castruccio Castracani di Lucca," in F. Gacta, ed., Istorie fiorentine (Milan, 1962), 3-41. 
month that witnessed the surrender of Montemassi, he had forced the capitulation of Pistoia, neutralizing the efficacy of a large Florentine army sent to relieve the siege. ${ }^{135}$ The Sienese felt proud of succeeding where the Florentines had failed. Indeed, fortune had smiled upon Siena because Castruccio fell mortally ill just about the time Pistoia fell. He died on 3 September, but this was kept secret until 10 September, the very day Siena greeted its victorious army. Speculation concerning Castruccio's sickness must have spread quickly and influenced both partisan and enemy. During his last days, aware of his approaching end, Castruccio's main concern was not the distant siege of a minor mountain fort but rather securing his possessions for his sons. In all probability, were it not for Castruccio's timely sickness and death, Guidoriccio would not be riding high in the $\mathrm{Pa}$ lazzo Pubblico. Surely, in Sienese eycs, Castruccio's involvement raised the action at Montemassi to epic status - the example of the commune resisting tyranny and overcoming overwhelming odds.

\section{APPENDIX}

\section{MAR'IINDALE'S INTERPRFTATION (OF TIHE} GUIDORICCIO FRESCO

In his recent article in the Burlington Magazine, ${ }^{136}$ Andrew Martindale affirmed Simone Martini's authorship of the Guidoriccio fresco yet separated its production from the siege at Montemassi, considering it painted instead at the occasion of Guidoriccio's victory near Giuncarico over the troops of Massa Marittima and Pisa of 14 December 1332. His arguments and their implications deserve close scrutiny. After objecting to some of Mallory's and Moran's arguments presented in the same issue of the Burlington Magazine, ${ }^{137}$ he considers the chronological sequence of the paintings situated on the same wall. Here he omits reference to Ambrogio Lorenzetti's Mappamondo's rotation marks, which extend across that portion of the lower central border of the Guidoriccio fresco that includes the date of 1328. He agrees with Mallory and Moran that the new fresco below Guidoriccio represents Arcidosso. And he maintains at the same time that Simone's Guidoriccio fresco depicts the Sienese general at the siege of Montemassi. This set of circumstances would by necessity assume the existence of two paintings of Montemassi located in the Palazzo Pubblico and dating a few years apart. Strangely, Martindale does not discuss the viability of this situation. If the new fresco

135 Giovanni Villani, Cronaca, x, 86

136 Martindale, "The Problem of 'Guidoriccio.".

137 Andrew Martindale, Burlington Magazine (April 1986). represents Arcidosso, then it must be the one drawn by Simone Martini in August of 1331. However, Simone Martini was already paid for painting Montemassi (together with Sassoforte) in May of the previous year. Guidoriccio's victory over the Pisans on 14 December 1332 was a decisive battle. For this victory Guidoriccio was knighted, and he was also rewarded with money and a silver chalice. We quote Agnolo di Tura's account of this victory.

Sir Guido Riccio, captain of the Sienese, hearing that the men of Massa and Pisa were riding through the Maremma ... [ with Sir Mocata of Sir Gabriello de Piccolomini of the nobles of Siena went] to Giuncarico and they assailed the men of Sir Dino and those of Massa, and they fought for some hours a greater and more ferocious battle than had been seen for a long time in this land of few armies; finally the men of Pisa and Massa were defeatcd with many dead and taken prisoner, and among the men of Massa and Pisa about 200 found their dcath ainong infantry and cavalry including many horses; and 90 of the Pisans and the men of Massa were taken prisoner, among them Sir Dino de la Rocha, the captain of the Pisans at Massa, with 6 constables on foot and on horse of the main gangs of the Pisans and the men of Massa; and all these 90 were led bound to Siena with the Pisan standards dragging and with much psalm singing by the arıny, and they arrived in Siena with much celebration and triumph.

And Sir Guido Riccio, captain of the communc of Siena was in front with the banner of the communc of Siena and around the prisoners were the soldiers and crossbowmen of the commune of Siena in ordered rows, and thus they entered the gate of Siena with much happiness on the first day of January ... for this victory the Siencse knighted the same Sir Guido Riccio, who prior to this was not a knight but was called sir ("missere"); for all the good and couragcous deeds he dicl all the time he was the captain of war of the Siencse ... the commune of Siena knighted him with great honour and at much cost, and gave him 500 gold florins in a silver cup valued at 30 gold florins. ${ }^{138}$

138 "Misser Guido Riccio capitano di'Sanesi ... sentendo come i Massetani e Pisani erano in cavalcata in Marema, di subito fè'intendere al capitano de le genti che era a la guardia de le tere presc, che era misser Mocata di misser Gabriello de'Piccolomini de'nobili di Siena, il quale immediatc fè'raunare sua gente de dette terre lassando fornite le dette tcrre e andò detto capitano di misser Riccio a Giuncarico e assaliro le genti di misser Dino e sua gente e Massetani, e ferì gran bataglia insieme per più orc, in modo che fù magiore bataglia e aspra che già gran tempo fusse nel paese di tanto poci esercito; a la fine i Massetani e Pisani furono sconfitti e molti morti e presi, e trovovisi morti de'Massetani e Pisani circa 200 tra pedoni e cavalieri con molti cavalli; e menorone presi 90 tra Pisani e Massetani, fra quali presi v'era misser Dino de la Rocha, capitano de'Pisani in Massa, con 6 conestabili a pie e a cavallo de'principali de lc masnade de'Pisani e de'Massetani; e tutti questi 90 furono menati legati in Siena co'lc bandiere de'Pisani strascinando con molta salmoria di loro oste, e gionse(ro) in Sicna con gran festa e triunfo.

"l. misser Guido Riccio, capitano del comuno di Siena era inanzi co'la bandiera del comuno di Siena c dintorno a'prigioni crano i soldati e balestricri del comuno di Siena 
Martindale's connection of the Guidoriccio fresco to this military action simply does not make good sense. Were this decisive victory to have been commemorated on the walls of the Palazzo Pubblico, the Sienese would have represented this very battle and the knighting of their victorious gen-

per ordine a le file, e cosi entroro a la porta in Siena con grande allegreza a di primo di genaio... per la detla vettoria i Sanesi fero cavaliere il detto misser Guido Riccio, che prima non era cavaliere ma si chiamava missere; per li buoni e valenti portamenti che lui a fatto tutto il tempo che è stato capitano della guerra de'Sanesi, come a suo tenpo avemo detto, el comuno di Siena lo fè'cavaliere con grande onore e spese, e donolli 500 fiorini d'oro in una coppa d'argento di valuta di fiorini 30 d'oro" (Agnolo di Tura, in Muratori, Rerum italicarum scriptores, cronache senesi, 507). Martindale indicates ("The Problem of 'Guidoriccio," $267 \mathrm{n} .35$ ) that on 21 January 1332 Guidoriccio is referred (o) as "nuovo cavaliere." eral. That they should then have decided, in the euphoria of victory, to refer retrospectively to a siege which concluded a patti live years earlier is not acceptable.

Nor does Martindale deal adequately with the new fresco's style. It is considered briefly and loosely, with cven Lippo Memmi emerging as one of the candidates competing for its creation. ${ }^{139}$ Given that Martindale connects both frescoes to Simone Martini or his ambient, one would expect a more thorough explanation of their considerable stylistic and technical differences.

For reasons already stated, Martindale's initial assumption, that the new fresco represents Arcidosso, leads him into inextricable difficulties.

139 Martindale, "The Problem of 'Guidoriccio," 271. 